Kahveci, T., Tınas, R. (2021). "Temel Anayasal Hak ve Hürriyetler Açısından 1982 Anayasasına Foucauldian Bir Bakış", Eskişehir Osmangazi Üniversitesi iỉBF Dergisi, 16(1), 55 - 86.

Doi: 10.17153/oguiibf.661397

Başvuru: 19.11.2019 Kabul: 20.10.2020

Araştırma Makalesi/Research Article

\title{
Temel Anayasal Hak ve Hürriyetler Açısından 1982 Anayasasına Foucauldian Bir Bakış ${ }^{1}$
}

\begin{tabular}{|c|c|}
\hline & $\begin{array}{r}\text { Turgay Kahveci }{ }^{2} \text { iD } \\
\text { Rukiye Tınas } \\
\end{array}$ \\
\hline $\begin{array}{l}\text { Temel Anayasal Hak ve Hürriyetler Açısından } 1982 \\
\text { Anayasasına Foucauldian Bir Bakış }\end{array}$ & $\begin{array}{l}\text { A Foucauldian Look at the } 1982 \text { Constitution in Terms } \\
\text { of Fundamental Constitutional Rights and Freedoms }\end{array}$ \\
\hline Öz & Abstract \\
\hline $\begin{array}{l}\text { Bu makalenin amacı Türkiye'de } 12 \text { Eylül } 1980 \text { darbesi } \\
\text { sonrası ortaya çıkan } 1982 \text { Anayasasını ve askeri yöneti- } \\
\text { min uygulamalarını temel hak ve hürriyetler açısından } \\
\text { Michel Foucault'nun hukuk-iktidar ilişkisi analizi üzerin- } \\
\text { den incelemektir. Öncelikle Foucauldian iktidar düşün- } \\
\text { cesi ve özneleşme pratikleri incelenmiş, ardından huku- } \\
\text { kun iktidar ilişkilerindeki konumu belirlenmiştir. Fouca- } \\
\text { uldian teorik çerçeve temel alınarak } 1980 \text { darbesi son- } \\
\text { rası hukukun iktidar ilişkilerindeki rolü ve temel hak ve } \\
\text { hürriyetlere karşı özel konumu ortaya çıkarılmıştır. }\end{array}$ & $\begin{array}{l}\text { This paper aims to analyze the Constitution of } 1982 \\
\text { drawn up after the coup d'État of } 12 \text { September } 1980 \\
\text { and military government practices, regarding funda- } \\
\text { mental rights and freedoms from Foucault's analysis on } \\
\text { the law/power relationship. Foucauldian thought of } \\
\text { power and subjectivization practices were first exam- } \\
\text { ined, the position of law in power relations was deter- } \\
\text { mined thereafter. Based on Foucauldian theoretical } \\
\text { framework, the role of law in power relations and its } \\
\text { special position towards fundamental rights and free- } \\
\text { doms after the } 1980 \text { coup d'État were revealed. }\end{array}$ \\
\hline $\begin{array}{l}\text { Anahtar Kelimeler: İktidar, Özne, Hakikat, Darbe, } 1982 \\
\text { Anayasası }\end{array}$ & $\begin{array}{l}\text { Keywords: Power, Subject, Fact, Coup d'État, Constitu- } \\
\text { tion of } 1982\end{array}$ \\
\hline JEL Kodları: D72, K10, Z18 & JEL Codes: D72, K10, Z18 \\
\hline
\end{tabular}

\begin{tabular}{ll}
\hline \hline $\begin{array}{l}\text { Araştırma ve Yayın } \\
\text { Etiği Beyanı }\end{array}$ & Bu çalışma bilimsel araştırma ve yayın etiği kurallarına uygun olarak hazırlanmıştır. \\
$\begin{array}{l}\text { Yazarların Makaleye } \\
\text { Olan Katkıları }\end{array}$ & Çalışmanın tamamı iki yazar ile birlikte oluşturulmuştur. \\
Çıkar Beyanı & Yazarlar açısından ya da üçüncü taraflar açısından çalışmadan kaynaklı çıkar çatışması bulunmamaktadır. \\
\hline \hline
\end{tabular}

\footnotetext{
${ }^{1}$ Bu çalışma, Eskişehir Osmangazi Üniversitesi, Sosyal Bilimler Enstitüsü, Siyaset Bilimi ve Kamu Yönetimi Anabilim Dalı’nda Doç. Dr. Rukiye Tınas danışmanlığında, Turgay Kahveci tarafından “Foucault Perspektifinden Türkiye'de 12 Eylül Askeri Darbe Döneminin Analizi (1980-1983)" ismiyle tamamlanarak 09.11.2018 tarihinde savunulan yüksek lisans tezinden türetilmiştir.

${ }^{2}$ Doktora Öğrencisi, Ankara Üniversitesi Siyasal Bilgiler Fakültesi, Siyaset Bilimi ve Kamu Yönetimi Bölümü. turgay_kahveci@hotmail.com

${ }^{3}$ Doç. Dr., Eskişehir Osmangazi Üniversitesi İktisadi ve İdari Bilimler Fakültesi, Siyaset Bilimi ve Kamu Yönetimi Bölümü rukiye_tinas@hotmail.com
} 


\section{Giriş}

1960 'lardan itibaren tarih, siyaset bilimi, felsefe ve psikiyatri gibi alanlarda derin etkiler yaratmış bir eleştirel kuramcı olarak tanınan Michel Foucault (1926-1984), Fransa'nın köklü kurumlarından olan Yükseköğrenim Okulu'nda (École Normale Supérieure) ve Lille Üniversitesi'nde dersler vermiş, ayrıca halka açık olarak işlediği ve felsefi düşüncelerinin temel öğelerini içeren derslerine Collège de France'daki "Düşünce Sistemleri Tarihi” olarak adlandırılan kürsüde ömrünün sonuna dek profesör olarak devam etmiştir. Foucault, felsefi hayatının ilk uğraklarından birini oluşturan "Deliliğin Tarihi" adlı doktora tez çalışmasını 1961'te tamamlamış ve bu eserinde uyguladığı üzere akademik çalışmalarını geleneksel düşünce tarihinin barındırdığı "doxa" ları deşifre etmek üzerine kurmuştur (Timur, 2005: 43-45).

Düşünür, deliliğin soy kütüğünden hastaya yöneltilmiş tıbbi bakışa, ortaçağın infaz sisteminden dönüşüm geçiren rasyonel devlet aklı ve iktidar olgusuna kadar tespit ettiği pek çok sorunsala farklı bir pencereden bakmaya çalışmıştır. Bu yaklaşım çerçevesinde iktidarın tarihini yazmaktan ziyade, iktidarın yazılmış tarihini dört ana eksene ayırarak yapısöküme uğratmıştır. Bu eksenler, tıp-delilik, bilim-bilgi, gözetim-hapishane, cinsellik-aile eksenleridir. Bununla birlikte, Hapishane Haberleşme Grubu (Groupe d'information sur les prisons, GIP) ${ }^{4}$ aracılı̆̆ıyla ceza reformları üzerine büyük uğraşlar da vererek aksiyonel girişimlerde de bulunmuştur (Tekelioğlu, 1999: 16).

Öte yandan Foucauldian kuramsal perspektifle birlikte, Türkiye tarihselliğinin Foucaultcu bir açıdan irdelenmesi iktidar ilişkilerinin yoğunlaştığı 1980 darbesinde olanaklı görünmektedir. Türkiye siyasi tarihinde askeri darbeler en büyük kırılmaları, sosyolojik ve toplumsal-psikolojik değişimleri barındırmaktadır. Türkiye'nin iç dinamikleriyle ve kendi tarihinde barındırdığı çatışmalarla doğrudan ilgili olan iktidar ve iç siyaset sorunu, pek çok kez askeri darbeler biçiminde de tecessüm eder. Bu hususta bakış açısını biraz değiştirmek gerekir. İktidar yalnızca bildiğimiz anlamıyla, makro düzeyde arzulanan bir olgu mudur? iktidar bir kişiye, bir siyasal zümreye, bir partiye teslim edilmiş güç müdür? Türkiye tarihinde her zaman siyasi elit olarak varlığını sürdürmüş ve siyasetin merkezine bir baskı grubu oluşturmuş olan Türk Silahlı Kuvvetleri (TSK), iktidar uygulayan ve daha geniş bir iktidar ağının parçası olan bir yapı mıdır sorusu bu hususta anlam kazanmaktadır. Böylece iktidara dair bakış açısı geliştirilirken Foucauldian perspektiften hareket etmek Türkiye siyasi tarihinde hukuk-iktidar ilişkisi özelinde de farklı bir düşünüm oluşturabilecektir.

Bu çalışmada iktidarın bilim-bilgi ekseninin teorik altyapısı referans alınarak, siyaset bilimi perspektifinden 12 Eylül iktidarı ve 1982 anayasası temel hak ve hürriyetler bakımından incelenmiştir. Araştırmanın temel sorunsalı Türkiye siyasi tarihinde baskının, gözetimin ve disiplinin en yoğun yaşandığı yıllar olan 12 Eylül darbe sürecinde iktidarın hangi mekanizmalar üzerinde kristalize olduğudur. Özellikle 1982 anayasası ile birlikte toplumsal norm ve hakikatin, dönemin

\footnotetext{
${ }^{4}$ GIP, Michel Foucault, Jean-Marie Domenach ve Pierre Vidal-Naquet tarafından 8 Şubat 1971 tarihinde imzalanan bir manifestonun ürünü olan bir eylem ve malumat hareketidir. Sadece entelektüellerin yer almadığı, heterojen bir yapıya sahip olan GIP’nin amacı mahkûmların konuşmalarına izin verilmesini ve cezaevi sistemine müdahil olan entelektüel ve profesyonellerin mobilizasyonunu sağlamak olmuştur. Basın ve radyonun hapishanelere giriş yasağının kaldırılmasında doğrudan etkisi olan GIP Aralık 1972'de kendini feshetme kararını almıştır. GIP hakkında detaylı bilgi için bkz. Artières, Philippe; Quéro, Laurent; Zancarini-Fournel, Michel (2003). Le groupe d'information sur les prisons, Archives d'une lutte, 1970-1972. Paris: IMEC Yayınları.

GIP Manifestosu için bkz. https://istiraki.blogspot.com/2016/02/gip-manifestosu.html (Erişim: 27.07.2020).
} 
iktidarı tarafından nasıl oluşturulduğunu ortaya koymak ve temel hak ve hürriyetlerin kısıtlanmasında hukuku Foucauldian iktidar bağlamına oturtmak önem arz etmektedir. Nitekim söz konusu dönem, ideolojik tutumlara, kimliklere ya da dünya görüşlerine savaş açarak, bazı kitapları "sakıncalı" addedip ve dahi yasaklayan bir anlayışın tezahürü olarak boyun eğdiren iktidar mekanizmalarını kullanmıştır.

Dolayısıyla, korkularla dolu bir toplumsal dokuyu oluşturan iktidar ağının tahakküme dayalı normatif sistemler üzerinden iktidarını bireylerin beynine nasıl işlediğini, söylemi ve dolayısıyla bilgiyi üreterek toplumda "sorunlu" olarak addettiği kişiler üzerinden kendisini nasıl var ettiğini ortaya koymak temel hedef olacaktır. Darbe iktidarının yarattığı makul insan, istenilen sınırlara hapsedilmiş, düşünmekten alıkonulmuş bir muhtevaya sahiptir. $O$, düşüncenin sınırlarını zorlaması durumunda düşünce suçlusu haline getirilen kişidir. Bu sorunlu öznenin nasıl parçalandığı ve yeni bir bilgi öznesinin nasıl yaratıldığı, dönemin hukuk-iktidar ilişkisi çerçevesinde yaratılan hakikatler ve bu hakikatlere dayalı sınır çizgilerine sabitlenmiş özgürlükler üzerinden incelenecektir.

Öncelikle yukarıda adı geçen "makbul insan" tasavvuru söz konusu olduğunda Füsun Üstel'in "makbul yurttaş" ${ }^{5}$ olarak adlandırdığı makbul insanın, Türkiye Cumhuriyeti'nin insan haklarına dayalı, lâik ve sosyal bir hukuk devleti olduğunu ve herkesin kişiliğine bağlı dokunulmaz, devredilmez hak ve hürriyetlere sahip ve kanunlar önünde eşit olduğunu bilen bir vatandaş tipini ifade ettiği söylenebilir. Üstel'e göre "makbul yurttaş", Atatürk devrimlerine bağlıdır, kanun ve nizamlara saygılıdır, ailenin en temel değer olduğunu kabul eder, milli kaynakları korur ve geliştirmeye çabalar (2004: 252).

Murat Belge ise makbul yurttaş adlandırması yerine "ideal Türkiye Cumhuriyeti yurttaşı" ifadesini tercih ederek şunları aktarır:

"ideal Türkiye Cumhuriyeti yurttaşı, her şeyden önce soru sormak gibi bir özelliği olmayan bir insan tipidir. Istiklâl Caddesi'nde kendisine yarı Almanca olmak üzere kimliğini göstermesi söylendiğinde," siz kimsiniz?" ya da "hangi hakla benden bunu istiyorsunuz?" sorusu aklına gelmez.

Ideal Türkiye Cumhuriyeti yurttaşı, gene her şeyden önce, otoriteye itaat etme alışkanlığını edinmiş bir insan tipidir. Babalarına, şeflerine, amirlerine, başkanlarına, iktidarlarına, yetkililerine itaat ede ede, itaati oksijen solumak gibi doğal bir davranış haline getirmişler.

Ideal Türk vatandaşı başının belaya girmesini istemez. Bu istememe durumunun, başının belâya fiilen girmesini ne derecede önlediği aslında çok belli değildir. Çünkü Türk vatandaşlarının başları sık sık belâya girer.

\footnotetext{
5 Üstel, "Yurttaşlık Bilgisi" ders kitapları çerçevesinde inşa edilen "makbul yurttaş" anlayışının dönemsel incelemesini yaparken, uyulması ve içselleştirilmesi gereken kurallardan oluşan "makbul” davranış kodlarının telkinine vurgu yapmaktadır. Cumhuriyetin 1950'li yıllara kadar süren yurttaşlık profilinde kültürel bir aidiyet duygusu ağır basarken, 1950'lilerden 1980'lere kadar geçen otuz yılda kültürel yurttaşlıktan siyasal yurttaşlık anlayışına geçiş söz konusudur. Bu anlayış çerçevesinde oy verme, askerlik yapma, vergi ödeme gibi hak ve görevler silsilesiyle tanımlanan bir yurttaşlık içeriği oluşturulmuştur. 1980 darbesini izleyen süreçte ise yurttaşlık kavrayışı yeni bir yönelim sergilemeye başlamış, milliyetçi referanslarla dolu ve İslamiyet ile güçlendirilmiş bir kültürel yurttaşlığa geri dönülmüştür. Bu dönemde milleti oluşturan maddi unsurlara "dil" ve "ırk" ile birlikte "din" de eklenmiş; bahsedilen özcü-kültürel yurttaşlık anlayışına "biz-onlar" çerçevesi dâhil edilmiştir. Bu hususta ırk unsuru, zihinsel seferberlik açısından katalizör işlevi görürken "sağlıklı toplum" olabilmenin güvencesini de oluşturur (Üstel, 2002: 277-283). Bu açıdan Üstel'in "sağlıklı toplum” ifadesini tercih etmesi, Foucault perspektifiyle bir paralellik barındırması bağlamında dikkat çekicidir.
} 
Ama belki de bu başı belâya girenler, yeteri kadar ideal olmayı başaramamış Türk vatandaşlarıdır" (1992: 322-323).

Bu makalede Belge'nin ifadesiyle 'yeterince ideal olmayı başaramamış Türk vatandaşları' nın 12 Eylül yıllarında maruz kaldıkları özneleştirme, sindirme ve kişiliksizleştirme türü politikalar, bilhassa bu tür politikaların arkasında yatan gerçekliğin yasal olarak dizaynı, yukarıda belirtilen Foucauldian teorik çerçeve referans alınarak analiz edilecektir.

Çalışmanın başlangıç noktası Michel Foucault'nun bir bütünlük barındıran iktidar teorisini incelemek olacaktır. Söz konusu iktidar teorisi, söylem, bilgi, özne, yönetimsellik, güvenlik ve disiplin denilen olguların tamamıyla sarmal ve sistematik bir ilişki içerisindedir. Bu anlayışa göre iktidar, bilginin içerisinde hükmeder, söylemle can bulur ve liberal yönetimsellik şematiği içerisinde özne kılma süreçlerini yaratır. Bu tip bir iktidar tanımı, güvenlik ve disiplin gibi kavramları, bu kavramların üzerlerinde kristalize olduğu kurumları meydana getiren birtakım dışlama prosedürlerini içermektedir. Tüm bu kavramlar ışığında ve filozofun oluşturmuş olduğu teorik altyapıdan hareketle 12 Eylül konjonktürü mercek altına alınabilir. Türkiye siyasi hayatına Foucauldian bir perspektiften bakılarak teori ile pratiğin uyumu irdelenebilir. Bu bağlamda analizi gerçekleştirirken iktidarı yapısöküme uğratmak ve post modern bir yaklaşım olarak söylemden başlamak yerinde olacaktır. Kuramsal çerçevenin ortaya konulmasının ardından Foucault'da iktidar ilişkisi bağlamında hukukun konumlanışı incelenecek, son olarak da somut tarihsellik bağlamında 1982 Anayasası koyucularının temel hak ve hürriyetlere karşı takındıkları tavır ve anayasanın hakikat kurucu misyonu analiz edilecektir.

\section{Michel Foucault Düşüncesinde Söylem ve Hakikat}

Söylem, özellikle 1960'lardan itibaren yükselişe geçen postmodernizm akımı ile birlikte sıkça başvurulan bir olgu haline gelmiştir. Postyapısalcılarda, yapısöküm uygulamalarında dil ve bilhassa söylem oldukça önemlidir. Söylem, sonsuz bir düzlemde sürekli olarak devinim halinde bulunan öyle bir olgudur ki, "Benim söylemim söylemler üzerine söylemdir" diyen Foucault (1999: 262) dahi daha sonraları Foucauldian söylemin ortaya çıkmasını engelleyememiştir.

Söylem söz konusu olduğunda dil temel rolü oynamaktadır. Esasen dil, belirli bir toplumsal düzendeki aynı türden nesneleri ve gerçeklikleri, o toplumun bünyesindekiler için anlamlı kılmaktadır. Başka bir deyişle dil, sembolleri aktarım işlevi gören, hatta kendisi dahi bir sembol olan karmaşık bir olgudur (Örs, 2014: 32).

Bu bağlamda siyaset bilimi alanını uzun yıllar boyu etkilemiş olan ideoloji kavramına kökten karşı çıkarak söylemi öne çıkaran Foucault, Marksist geleneğe de savaş açmıştır. Düşünür, ideoloji yerine söylemi öne çıkarmış, hatta ideoloji karşıtı bir tutum takınmıştır. Foucault, ideolojinin, doğrunun karşıtı bir konum aldığını söyler. Zira doğru olan söylemin doğru dediğidir ve bu durumda söylemin nası üretildiği önem arz etmektedir. Marksist ideolojide olduğu gibi üretim araçlarına sahip olan ve üretimin maddi koşullarını elinde bulundurarak üst yapıyı son kertede belirleyen hegemonik bir blok bütün denklemi çözmemektedir. Yine ideoloji kavramı, verili bir özneye gönderme yapar. Bu verili özne, ideolojinin yükleneceği, önceden kurulmuş, tarih dışı $a$ priori özneyi varsaymaktadır. Oysa özne, herhangi bir sınıf veya çıkar, söylem onu üretmişse mümkündür; o, dilsel ve toplumsal pratiklerin ürünüdür (Örs, 2014: 37-38). Foucault, ideolojiyi öne çıkaran analizlerde kendisini rahatsız edenin, modelini klasik felsefeden alan ve iktidarı ele geçirebilecek bir bilinçle donanmış insan öznenin her daim sunuluyor olması olduğunu ifade eder (2015b: 42). 
Louis Althusser (1978: 63)'de ideolojinin bireyi çağırması, Foucault'da ise söylemin bireyi kurması söz konusudur. Söylemler, insanların ve kurumların üzerinde baskı üretirler ve kendilerine bir belirginlik, haklılık kazandırırlar. Ona göre, kendi kültürleri içerisinde insanlar söylem devinimleri içerisinde özne ${ }^{6}$ kılınırlar (Güneş, 2013: 64). İşte G. W. Friedrich Hegel'den bu yana, ilerlemeci tarih anlayışının önerdiği a priori özneye karşı, tarihin her döneminde farklı şekillerde kurulan özneler, iktidarlar, bilgi, söylem ve hakikatlerden oluşan sarmal bir ağ mevcuttur.

Foucault için söylem, dilbilimsel ve stratejik olguların düzenli bir toplamı olan kompleks bir işleyiştir (Becermen, 2009: 125). Bu şekliyle söylem, tek başına değil; hem onunla birlikte işleyen, hem onu üreten kurumlarla bir bütün içinde çözülebilir. Böylece söylem; dışlamanın, denetlemenin, kendisini özellikle cinsellik ve politika alanlarında gösteren yasağın, tabunun, tek tip hakikat dayatılışının başat faktörü haline gelir. Kendini hiçbir zaman açığa vurmaksızın, gizli ve belirsiz şekilde baskıyı üreten söylem; karşısında saygı duyulan, dehşete düşülen, hakikati bildirdiği için uyulması gereken ve herkese adalet dağıtan bir "doğruluk" niteliği taşır.

Böylece Foucault, söylemden bahsederken onunla bütünleşik bir hakikatten de bahsetmektedir. Hakikati kim söyler? Hâkim söylemi belirleyenin hakikatle kurduğu bağ ne tür bir ilişkidir? Foucault burada akıllı-deli karşıtlığı üzerinden örnek verir. Orta çağda deli, söylemi yayılma imkânı bulamamış, söyledikleri hiç söylenmemiş gibi sayılan, kayda değer bulunmayan ya da kiliseye göre kutsal sayılan bedenini emeğe dönüştüremeyen kimse olarak görülmüştür (Güneş, 2013: 57-59). Bu konumuyla deli örneğinde, bir hakikat dışılık görülür. Kilisenin söylemine göre deli, söylemi hakikatle bir bağı olmayan ve gerçekliğin dışında söylemleri olan kimsedir. Foucault burada bakış açısını farklı bir yere kaydııı. Peki, hakikat denilen şey nedir?

Hakikat, bilimsel bir söylem biçiminin ve bu söylemi üreten kurumların merkezinde ortaya çıkmaktadır. Sürekli olarak ekonomik ve siyasi teşvik altında, çeşitli biçimlerde geniş çaplı bir dağııımın ve tüketimin nesnesidir. Yazılı ve görsel medyanın, basım ve yayının, üniversitenin ve ordunun baskın denetiminde üretilerek dolaşıma sokulur. Bütün bir toplumsal çatışmayı ilgilendiren bir sorun olarak hakikat, keşfedilecek hakikatler bütünü değil; doğru ile yanlışın birbirinden ayrıldığı, doğrulama veya yanlışlama biçiminde işleyen ve birtakım spesifik iktidar etkilerinin yüklendiği bir kurallar bütünüdür. Bu biçimiyle hakikat, kendisini üreten iktidar sistemleriyle ve kendisinin meydana getirdiği, kendisini yayan iktidar etkileriyle sürekli ve döngüsel bir ilişki içindedir. Burada sorun, insan bilincini ya da kafalarının içindekini değil, hakikati üreten bütüncül bir ekonomi-politik, kurumsal rejimi değiştirmektir. Siyasal sorun; bir yanılgı, ideoloji ya da yabancılaşmış bilinç değil bizzat hakikatin kendisidir (Foucault, 2011: 83-85).

Düşünür ayrıca hakikatten söz ederken, spesifik iktidar etkilerinin doğru olarak kabul edilen söylemler etrafında nasıl kurulduklarını göstermeye çalıştığını ifade eder. Fakat onun asıl sorunu, çağdaşımız olan gerçekliğimiz üzerinde ve kendimiz hakkında bir analiz, bir siyasal eylem alanı açmak ve müdahalenin aygıtlarını geliştirmektir (Foucault, 2015b: 184).

Hakikatin söylem içerisinde bütünleşik işleyişi sonucu hakikat rejimi denilen durum ortaya çıkar. $\mathrm{O}$, kendisini üreterek yayan iktidar sistemleriyle ve iktidar ilişkileriyle sürekli ilişki içinde-

\footnotetext{
${ }^{6}$ Özne kelimesi iki anlam ihtiva etmektedir. Fransızcada sujet ve İngilizcede subject şeklinde ifade edilen özne, hem krallığa tabi bir uyruk anlamına gelirken hem de tarihsel bir özne anlamına gelmektedir. "Kral X'in (veya $Y$ toplumunun uyrukları)" ile "tarihin özneleri" şeklinde iki ayrı anlam barındıran özne, ilkinde belirli bir düzene tabiiyet içerirken ikinci anlamında bir şeyin yaratııısı veya yapıcısı anlamı taşımaktadır (Therborn, 2008: 29). Foucault'nun özne kullanımında bir bağımlılık yoluyla başkasına tabi olma ile vicdan ya da özbilgi yoluyla kendi kimliğine bağlı olma durumu, ayrı ayrı içerilir (Foucault, 2016: 63).
} 
dir. Hakikat bu dünyaya aittir ve çok çeşitli baskı mekanizmaları sayesinde ortaya çıkar. Her toplumun kendi hakikat rejimi ve kendine özgü genel bir hakikat siyaseti mevcuttur. Hakikat rejimi veya "hakikat oyunu", muhakkak suretle iktidardan ayrı değildir, onun tarafından üretilerek bilinçten bilince yayılır (Becermen, 2009: 139-140). "Bu, bir anlamda iktidar olan bir hakikattir ve kendini hakikat olarak pazarlayan bir iktidardır" (Gödelek, 2011: 59).

Foucault, "hakikat oyunu" terimini kullanırken, hakikat üretiminin kurallar bütününü, belli bir sonuç doğuran prosedürler bütününü kasteder. Hakikati söyleyenleri ise; özgür olan, kendilerini birtakım iktidar pratikleri ve kısıtlayıcı kurumların ağına girmiş durumda bulan bireyler olarak nitelendirir (2016: 242). Yine de iktidar söylemlerinin oluşturdukları tüm bu hakikatlerin tarihsel ve aşılabilir olduğunu belirtir. Ona göre tarihsel söylemin kurduğu bireysellik dönüştürülebilir (Akgündüz,2013: 5). Bu hususta: "Söylemi değiştirmenin olanağını inkâr etmedim, öznenin egemenliğinden geri aldım" der (Foucault, 1999: 267).

Söylem şüphesiz değiştirilebilir, böyle dinamik bir teori içerisinde statik bir yapı, sıkı sıkıya bağlanılan ideoloji kalıplarını hatırlatan durağan bir durum söz konusu değildir. Foucault için değişim mümkündür ancak öncelikle iktidar, bilgi, özne olguları ve bunlarla iç içe geçmiş girift bir devlet aklı olarak liberal yönetimsellik, buradan doğan bir güvenlik ve disiplin toplumunu analiz etmek gerekmektedir.

\section{Michel Foucault Düşüncesinde İktidar, Bilgi ve Özne}

Söylemsel dolaşım alanında konumlanan hakikat oyunları Foucault'da iktidar etkileri yaratan çoklu ilişkiler alanının incelenmesini beraberinde getirmektedir. Foucault açısından iktidarın "yöneten sınıflar" düzeyinde kategorize edilmesi, "Kim, nasıl ve kimler üzerinde iktidar uygular" sorularına, burjuvaziyi tüm form ve stratejileriyle hükümran özne olarak işaretlemek suretiyle kısmen doğru ancak yetersiz bir yanıt verir. İktidarın işleyişi çok daha kompleks olup (Foucault, 1988: 103), bilginin iktidar işlevinden öznenin inşasına kadar ilişkisel bir bütünlüğü barındırmaktadır. Böylece söylem ve hakikatten bilgi ve özneye uzanan iktidarın kuşatıcı ağı söz konusu olmaktadır.

\subsection{Foucault'da İktidar}

Michel Foucault'nun iktidar çalışmaları, oldukça merkezsiz, adeta kaygan bir zeminde her yöne hareket eden bir ilişkiler çokluğu biçiminde benzersiz grafik çizer. Politik hiçbir kuram içerisine kendisini kapatmadan, iktidar üzerine özgürce düşünen ilk filozof olarak Foucault'yu etkileyen en büyük isim, geniş bir perspektifle odağını iktidar ilişkilerinin özüne dikmiş olan Friedrich Nietzsche'dir. Bu etkilenme ile bir anlamda "zerdüştlüğü" olumlayan filozof; bir ağ gibi, iplikleri her yere uzanan iktidarı incelemiştir (Sarup, 2004: 110-111).

Düşünür, hayatının son dönemlerinde yapmaya çalıştığının, esasen bir özne teorisi ortaya koymak olduğunu, araştırmalarının genel temasının iktidar değil özne olduğunu ifade etse de; Foucault'nun kuramında bilgi, iktidar ve özne birbirinden ayrılmaz (Foucault, 2000: 327).

Foucauldian perspektifte iktidar, ne toplumsal sözleşme kuramcılarının savunduğu gibi rızaya dayalı bir sözleşme, ne de sol literatürde olduğu gibi devrimle ele geçirilecek bir yapıdır. iktidar ilişkileri, bir yanda iktidara sahip olanlar ile diğer yanda ona sahip olmayanlar arasındaki şematik biçimiyle algılanamaz. Bir tarafta birkaç kişi varken diğer tarafta yığınlar yoktur. iktidar ilişkileri her yerden geçer, herkes iktidar uygular. Bir grup, bir sınıf veya toplum içinde iktidar halkalarının işleyişini bilmek; her bireyin, bu iktidar ağının neresinde konumlandığını, iktidarı 
nasıl yeniden uyguladığını, koruduğunu ve yansıttığını analiz etmek gerekir (Foucault, 2016: 160-161).

Tüm bunlara ek olarak, iktidarın rıza göstermeyle bir bağı olamayacağını, onun bir eylem kipi olduğunu belirtmek gerekir (Eroğlu, 2016: 44-53). Hem modern sözleşmeci iktidar geleneğine hem Marksist ideologların kalıplarına saldıran Foucault, Sovyetler Birliği örneğini ele alır. Devrim sonrasında ailede, fabrikada ve okullarda iktidar ilişkileri sabit kalmıştır. Problem, günümüz modern rejimlerinde mikroskobik düzeydeki iktidar ilişkilerinin dönüştürülebilirliği problemidir. Aksi halde, verili bir toplumda, siyasal-ekonomik herhangi bir devrimde, günümüz iktidar ilişkilerinin aynısına rastlanacaktır (Foucault, 2015a: 275).

Böylece filozof için iktidarın kaynağının veya iktidarın birikim noktasının devlet olduğu düşüncesi ve devletten hesap sorulması gerektiği fikri, iktidarı salt devlete indirgemesi bağlamında verimsizdir. Devlet iktidar uygular, devletin dışında bir aile reisinin çocuklara, bir hekimin hastaya, patronun fabrika işçilerine uyguladığı da iktidardır. İktidar, hayatın kılcal damarlarında öylesine kapsamlı işler ki, bir öğretmen öğrencisini, bir konuşma esnasında dahi taraflardan biri diğerini yönetir (Foucault, 2011: 324).

Daha anlaşılır kılmak açısından Foucault'ya benzer biçimde çoklu iktidar ilişkilerini ve onun mikroskobik etkilerini ele alan Maurice Duverger de aynı soruna odaklanmış, iktidar denilen olgunun nasıl uygulandığını araştırmıştır. İktidar, yalnızca merdivenin en alt basamağında bulunan ve hiç yönetmeksizin yönetilen yurttaşlara mı uygulanmaktadır? Aksi durumda, hiç yönetilmeksizin daima yöneten bir devlet başkanı iktidarın dışında mı kalmaktadır? Bu durumda, eşit olmayan insan toplulukları arasında bir bireyin diğerini boyun eğmeye zorladığı her durum iktidar olarak mı tanımlanacaktır? Duverger bu soruları sorar ve bir çözümleme getirir. Ona göre, bir bireyin diğerini herhangi bir şeyi yapmaya zorlayabilmesi olgusuna "etki" denir. Tüm insan ilişkileri arasında mutlaka var olan etki, iktidarın yalnızca özel bir kategorisi olarak tanımlanmalıdır (Duverger, 1995: 21).

Yukarıdakilerden hareketle, bir toplumda binlerce iktidar ilişkisi, küçük çatışmalar ve mikro mücadeleler vardır. Foucault, tüm bu iktidar ilişkilerinin bir devlet iktidarı ya da sınıf tahakkümü tarafından yukarıdan yöneltildiklerinin kısmen doğru olabileceğini ifade eder. Bunu paralelinde, söz konusu tahakkümün var oluşunun, tabandaki küçük iktidar ilişkilerinin varlığı sayesinde mümkün olabileceğini de belirtir. Tabandan yükselerek her yöne hareket eden mikro mücadeleler sayesinde tepedeki o görkemli iktidar işler. "Ya bunu yaparsın ya seni öldürürüm!" diyen kaba bir tahakküm düşünmemek gerekir. Olsa dahi bu, iktidarın en aşırı durumudur. Esas olan her zaman tersine dönebilecek çatışmalar veya güç ilişkileridir. Tamamen muzaffer olan, dolayısıyla tahakkümü durdurulamayan iktidar ilişkisi tasavvur edilemez (Foucault, 2015b). Çünkü bir toplumda yaşamak, mutlak suretle, birilerinin, başkalarının eylemlerini etkileyebildiği bir tür süreci beraberinde getirir. Bu güç ilişkilerinden azade bir toplum sadece bir soyutlama olacaktır (Foucault, 2000: 343). İktidar, ne bir mülkiyet ne de yalnızca basit anlamıyla bir kaba güç değildir. Iktidar, içerisinde o ilişkinin etkili olduğu terimler vasıtasıyla incelenebilecek bir ilişkidir (Foucault, 2015c: 178).

İktidarı, bir töz olarak görmemek gerekir. O, kökeni uzun uzadıya araştırılacak çok esrarengiz bir olgu da değildir. Üretimle, mübadeleyle ya da iletişimle birleşebileceği doğru olsa da iktidar yalnızca bunlara indirgenemeyecek spesifik bir ilişkidir. Burada Foucault, tahakküm ile iktidar arasındaki farkın altını çizmektedir. Zincire vurulup dövülen bir adam üzerine bir güç uygulanır fakat buradaki kaba güç, iktidar değildir. Eğer ki iktidar, bireyi özgür kalabilecek halde tutuyorsa, bu özgürlük ne kadar kapsamlı olursa olsun iktidar o bireyi yönetimine tabi kılmış demektir. 
Potansiyel bir başkaldırı, bir reddediş olmaksızın, iktidardan bahsedilemez. Aksi halde orada iktidar değil, basitçe bir tahakküm vardır. İktidar, özgür özneler üzerinde ve yalnızca onlar özgür oldukları sürece uygulanabilir. Kölelik, insan zincirlere vurulu olduğunda değil hareket edebilecek ve hatta kaçabilecek potansiyeli var olduğu müddetçe bir iktidar ilişkisidir. İktidar ilişkisinin temeli, istencin boyun eğmeyişi ile özgürlügün inadı arasındaki gerilimde yatar (Foucault, 2016: 55-76).

Bu şema içerisinde iktidar, direnişle ontolojik bir bağ içerir. Foucault, 1960'lı yıllarda "çekişme" (contestation), "ihlal etme" ve "çiğneme" (transgression) terimlerini kullanırken 1970'ler ve 1980'lerde "mücadele" ve "direniş" kavramlarını ağırlıklı olarak kullanmıştır (ışık, 2012: 108). Düşünüre göre bir iktidar ilişkisi tamamen dengesiz olduğunda bile o başkası için kendini öldürme imkânı açık olursa, orada bir iktidar ilişkisi vardır denilebilir. Yani iktidar ilişkilerinde her zaman direniş imkânı da mevcuttur. Nerede iktidar varsa orada koşulsuz olarak özgürlük de vardır (Foucault, 2016: 236).

Öte yandan direniş demek, iktidarın kendi oyununun ve söyleminin dışında bir söylem üretmeyi de gerektirir. Özünde iktidarın söylemini ve oyununu reddediş vardır (Becermen, 2009: 169). Bu anlamda direniş, yine söylem ve "hakikat oyunu" kavramlarıyla bağlantılıdır.

Foucault'nun iktidar teorisinin katmanları arasında ilerledikçe başka sorular sormak ve o soruların cevaplarını parça parça birleştirerek teoriye genel anlamda hâkim olmak gerekmektedir. Bu bağlamda şimdi sorulacak soru; özgürlüğü, kendi varoluşunun önkoşulu olarak sunan bir iktidarın, söylemi üreten ve söylem boyunca ilerleyen bir iktidarın, hakikat biçimlerini öne süren bir iktidarın, bunu daha derinlerde yatan hangi gücün etkisiyle gerçekleştirebildiğidir? Eğer ki iktidar, yalnızca yadsıma, olumsuzlama şeklinde işliyor olsaydı bu denli başarılı olabilir miydi? iktidarın tek işlevinin bastırma nosyonu olması oldukça yetersiz bir açıklama olacaktır. Iktidar yalnızca büyük bir üst-ben, bir sansür, engel, dışlama veya içe atma biçiminde işlemez. Eğer ki salt negatif bir eylem kipiyle işliyor olsaydı çok dayanıksız olurdu. İktidar şayet bu kadar güçlü ise, arzu ve bilgi düzeyinde pozitif etkiler üretmesi sayesindedir. Iktidar bilmeyi engellemek bir yana, bilgiyi üreten bir mekanizmadır. Var olan ne varsa, iktidar ve bilgi arasındaki ilişkinin ürünüdür. Filozofa göre, iktidar bu bağlamda sinsidir. Yalnızca baskı üretmez; arzu yaratır, zevki kışkırtır, bilgiyi üretir. Bunlardan çok daha derinlere nüfuz eder. İtidar bastırmakla, gerçeğe ulaşıımasını veya söylemi engellemekle kalmaz; arzu ve zevkle eklemlenir, davranışa nüfuz eder ve bedeni çalıştırır. Iktidar sevimlidir, yasağın içselleştirilmesine dayalı değil, bilgiyi üreterek yaymasına dayalıdır (Foucault, 2015b: 42-74). Böylece iktidar, bilginin üretiminden yayılımına kadar uzanan bir çerçevede işlev görür

\subsection{Foucault'da Bilgi ve Özne}

"Bilginin belirli bir anda icat edildiğini söyleyen Nietzsche'nin patavatsızlığını dikkate alacağım" diyen Foucault'nun en çok etkilendiği isimlerin başında yukarıda da belirtildiği gibi Nietzsche gelir (Foucault, 2015a: 169). Bu anlamda bilginin tanımını yaparken Nietzsche'den başlamak gerekir. Onun için bilgi, kökünde iktidar, mücadele ve kin merkezlidir. Nietzsche'nin düşüncesinde filozoflar, bilgiyi hep barışçıllık, uygunluk ve aşk olarak düşlediği için yanılgıya sürüklenmişlerdir. Bilginin kökü gerçekten bilinmek isteniyorsa filozoflardan çok politikacılara bakmak gerekir. Yaşamın kendisinde güç istencine dayalı mücadelenin ve iktidar ilişkilerinin analizini yapmak gerekir. Bilgiye olan böyle bir yaklaşımın sonucu olarak bilginin iktidar olduğu aşikârdır. Bilgi/hakikat ve iktidar arasındaki doğrudan bağ sonucu, toplum içerisindeki en güçlülerin bilgiyi dağıttığı ve kendi çıkarlarına göre meşrulaştırdığı görülür. Bilgi, bir doğrulama ve 
"hakikat oyunu”nun dayanağıdır. Bilgi meşru kılar. Böylece iktidar toplumdaki her yere, her noktaya yayılır, nüfuz eder (Becermen, 2009: 137-198).

İktidarı böylesine kudretli kılan bilgi, söylemde kendisinden bahsedilen, olguları tanımlayan şeydir. Foucault, homojen ve kuramsal olan, aynı zamanda arkeolojik çalışmayla elde edilebilen bilgiyi "bilme (savoir)" olarak adlandırırken; derinliği olmayan, yüzeysel ve heterojen olan ve soykütüksel çalışmalarla elde edilen bilgiyi ise, "bilgi (connaissance)" biçiminde niteler (Urhan, 2007: 101-102). Bu ayrımda "derinlemesine bilgi", bir söylemsel uygulama tarafından düzenli biçimde oluşturulmuş ve bilimin kuruluşu için gerekli unsurlar toplamıdır. Aynı zamanda kavramların ortaya çıktıkları, dönüştükleri, uygulandıkları, tanımlandıkları alandır (Foucault, 1999: 233). Bir başka deyişle, tarihin belirli bir anında ortaya çıkmış söylemi, söylemde bulunanın işlevi olarak değil, söylenilen cümlelerin tümünün ifade edilmesini sağlayan koşulların işlevi açısından çözümleyen ve arkeolojik çalışmaların konusu olan bilgi türü türüdür (Foucault, 1999: 233). Bu çerçeveden bir dokunun tarihini çözümlemek, derinlemesine bilginin alanına girer ki arkeolojik yöntem de düşünürün bu türden yapısökümcü bilgi teorisinde yer alır. "Connaissance" olarak adlandırdığı epistemik tanım ise bilimsel alanlar için geçerli olan yüzeysel bilgi alanına denk düşer. Bilme ile bilgi arasında zıtık barındıran bir ilişkinin bulunduğunu belirtmek gerekmektedir (Urhan, 2010: 57-59).

Foucault'nun yapısökümcü bilgi teorisinde esas aldığı ve çözümlemeye çalıştığı bilgi türü "derinlemesine bilgi"dir (Çelebi, 2013: 515). Onu arkeolojik çalışmalara iten de bu derinlemesine bilgi olmuştur. "Kelimeler ve Şeyler" isimli eserini yazarken de, insan bilimlerinin arkeolojisini oluştururken de bilgiden hareket eder. Söz konusu eser, bilginin, tek bir seferde bulunup ebediyete kadar geçerli ve verili olmadığını; daha çok bir "épistémè"nin7 çerçevesinde belirdiğini ortaya koymaktadır (Foucault, 2001b: 10).

Daha açık bir ifadeyle bilgi, kişinin herhangi bir söyleminde söz edeceği nesnelere anlamlarını veren alandır. İnsan, söylemsel pratik içerisinde gönderme yaptığı nesnelerden söz ederken ya da onları tanımlarken bunu bilginin alanında yapar. Bir kimse, nesneler alanı üzerine konuşacak olsa, pozisyon alabilmesi için o nesneler alanını tanımlayabileceği ayrı bir alana, bilginin alanına ihtiyaç duyar. Bilgi, kişiye üzerine konuşacağı şey hakkında, onda bir hakikati belirleme ve bir gerçeklik tayin etme olanağı verir. Bilginin alanı sayesinde bir şey üzerindeki hakikati belirlemiş olan biri, bunu söylemine de eklemleyerek o şey üzerinde iktidar yürütmeye başlar. Metin Becermen'e göre (2009), "iktidar ve bilme tam da söylem içerisinde eklemlenirler". O andan itibaren orada düpedüz bir iktidar ilişkisi vardır. İktidar/bilgi eklemlenmesi bir süreç içerisinde işler. Illk olarak bireylerden bilgi elde etme vasıtasıyla bir iktidar sağlanır, sonrasında ise denetim ve gözetim altına alınan bu bireyler üzerinde bir iktidar oluşturulur. Önce bilgi elde etme yoluyla bir iktidar, daha sonra bu bilginin iktidar olarak kullanılması söz konusudur (Eroğlu, 2016: 51).

Modernizm ile birlikte bilimsel bilgi alanları gelişerek (tıp, psikiyatri, kriminal bir alan olarak suçluluk, cinsellik) bir hakikat üretmiş ve onu bireye bilimsel bir doğru olarak dayatmaya başlamışlardır. Bu durum beraberinde normalleştirme, dışlama ve denetleme, özneyi kendi kimliğine bağlama süreçlerini getirmiştir. Yani Foucault'ya göre Aydınlanma düşünürleri yanılmıştır. İktidar ile doğrudan birbirini içeren bilgi aslında bir özgürleşme aracı değil; iktidarın denetim aygıtlarından biri olarak işlev görür, bireyleri hapseder (Çelebi, 2013: 515-516). O halde, bireylerin

\footnotetext{
${ }^{7}$ Foucault açısından épistémè kavramı, belirli bir entelektüel bağlam içerisinde düşünülen ve söylenenleri belirleyen tarihsel düşünce yapılarını açıklamaktadır. Épistémè, zamana ve kültüre bağlı olarak bir söylem çerçevesi meydana getirir (Cevizci, 1999: 306).
} 
üzerine direkt etki eden bilgi/iktidar bağı, odak noktasını doğrudan özne kılınan insana doğru, yani Foucault'nun asıl problemi olduğu düşünülen özne teorisine çevirir.

Özne, düşünür için merkezdeki problemdir. Bu anlamda politik teknolojinin gelişiminde Aydınlanma çok önemli bir aşama olsa da, insanın kendi tarihine nasıl hapsolduğunu bilmek için daha dolaylı yollara başvurmak gerekir. Foucault için bugün hedef bellememiz gereken, ne olduğumuzu keşfetmek değildir; olduğumuz şeyi reddetmektir. Bize ne olduğumuzu söyleyen, kimlik veren, bizi özneleştiren ve belirli türden bir öznelliğe bağlayan işleyişi sorgulamak gerekmektedir (2000: 326-336). Bu anlamda düşünüre göre, kendimizle kurmamız gereken ilişkiler kimlik ilişkileri olmamalıdır. Daha ziyade farklılaşma ve yeniden yaratma ilişkileri olması gerekir. İnsanlar zevklerini hangi kimlik içerisinde buluyorlarsa o kimlik dışlanmamalıdır. Modern iktidarların yaptığı gibi özne kılmak üzere herhangi bir kimlik evrensel bir etik olarak dayatılmamalıdır (Foucault, 2015b: 282).

Foucault, bu hususta temel araştırma nesnesini oluşturan Batı kültüründe özneleştirme süreçlerini incelerken, özneleştirme üzerinde etkili olan nesneleştirme kipleri üzerinde durur. İlki, kendisine bilim statüsünü veren, konuşan, emek üreten ve biyolojik olarak yaşayan özneyi nesneleştiren araştırma kipidir. İkinci olarak özneyi başkalarından ayırarak bölen ve onu marjinalleştiren pratikler yer alır. Son olarak ise, insanın kendini özneye dönüştürme pratikleri, "kendilik pratikleri (pratiques de soi)" adıyla Foucault'nun inceleme alanını oluşturmaktadır. Özellikle "bölücü pratikler (pratiques divisantes)" diye adlandırdığı ikinci tür pratikler, özneyi hem kendi içinde hem başkalarından ayıran pratiklerdir ve bu süreç özneyi nesneleştirmektedir. Deli ile akıllı, hasta ile sağııklı ve suçlular ile "iyi çocuklar" ayrımları bölücü pratiklerden olup, bu pratikler sorunsallaştırma kavramıyla örtüşür (Keskin, 2015: 14-15).

Sorunsallaştırma, tarihin belirli anlarında bazı davranış biçimlerinin sorun olarak görülüp söylemsel pratiklerin nesnesi haline getirilmesi ve düşünürün "hakikat oyunu" dediği sistemlere dâhil edilmesidir. Bahsedilen bu davranış biçimleri, bilgi ve hakikat üzerinden kurulur ve tanımlanır. Bu şekilde bu davranış biçimleri sınıflandırılır (normal, kriminal, patolojik gibi). Insanlar bu hakikatlere inandıklarında, o hakikatin tanımladığı deneyim biçimini kabul edip o deneyim biçiminin öznesi olmayı kabul ederler. Yani söz konusu olan, delilik, hastalık, suç gibi belirli davranış biçimlerinin veya varlık biçimlerinin sorunsallaştırılarak özel deneyim alanlarına dönüştürülmesidir. İnsanlar, bu deneyimin öznesi olmayı kabul edip davranışlarını bu normlara göre sınırlarlar. Bu şekilde, modern kapitalist toplumun gereği olan disiplin içselleştirilmiş olacaktır (Foucault, 2015a: 14-16).

Böylece rasyonalitenin ve insan bilimlerinin gelişimi sonucu psikiyatri, adli tıp gibi bilimler, dayandıkları bilgi sayesinde iktidar uygulamaya, bireylere hakikati göstermeye, normal olanı işaret etmeye ve normal olmayanı ayrıştırarak dışlamaya; onları kapatmaya, ıslah ve tedavi etmeye başlamışlardır. Bazı davranış biçimleri; psikiyatri ve psikopatoloji gibi insan bilimlerinin söylemleri ile eklemlendiğinde, artık bu davranış biçimleri üzerine konuşan otorite din veya ahlak olmaktan çıkmıştır. Söz konusu davranış biçimleri insan bilimlerinin kavramları arasına girmektedir. Daha açık bir ifadeyle; örneğin bir bilim olarak psikiyatri, belirli tür davranış biçimlerini patolojik vaka, belirli tür davranışları ise normal olarak belirler. Bunu psikiyatri biliminin bilgisi ve hakikati gösterme gücü ile yapar. Psikiyatriye göre birtakım davranış biçimleri akıl hastaIığının, diğer birtakım davranış biçimleri ise "normalliğin" göstergesidir. Bu davranış biçimleri, psikiyatrinin bilgisi ve söylemi neticesinde öznel deneyim alanları olarak sunulurlar. Toplumdaki her birey, psikiyatrinin bu söylemi tarafından kuşatılarak bir "hakikat oyunu" na girerler. Bu, çok basit anlamıyla bireyin kendisi üzerinde bir otokontrole benzer. En basit şekliyle şöyledir: "Ben 
şu davranış biçimlerini sergilemiyorum, o halde normalim!". Işste "hakikat oyunu", bireyin kendisini doğrulama sistemi olarak işler. Toplum, psikiyatrinin bu söylemi doğrultusunda kendi kendisini bir hakikat rejimine tabi kılar ve kendisini bu davranış biçimleri üzerinden sınar. Bunun sonucunda o birey, kendisinin bilgisine ulaşarak kendisini özbilgi yoluyla kendi kimliğine bağlamış olur. Bu şekilde iktidar, bireyi hem özneleştirmiş hem de nesneleştirmiştir. Nesneleştirir, çünkü toplumdaki her birey, bilimsel bir bilgi dalının (psikiyatrinin) birer nesnesi haline gelmiştir. Özneleştirir, çünkü her birey, bilim dalları tarafından kavramsallaştırılan bu davranış biçimleri veya deneyim alanları üzerinden kendisini sınar, kendi kimliğini tanımlar ve kendisini özne olarak kurar. Birey, bu bilim dallarının söylemlerini bilimsel bir hakikat olarak kabul ettikten sonra kendiliğinden yapacağı şey sorunlu ve patolojik olan davranış biçimlerinden vazgeçmek olacaktır. Vazgeçemese dahi vazgeçmek için kendisi üzerine büyük bir iktidar uygulaması gerekecektir. Dolayısıyla iki ayağı olan bir kimliklendirme ortaya çıkar: birincisi o kimliği taşımak istemeyenin kendi rızasıyla o kimlikten vazgeçmesini (eşcinselin kendi rızasıyla cinsel edinimini değiştirmesini veya siyasi fikirleri sebebiyle suçlu addedilmiş birinin bu davranış biçiminden uzaklaşmasını) sağlamak, ikincisi ise o kimliği reddedemeyenleri kapatmak, ıslah etmek (Keskin, 2017).

Hapishaneler ve akıl hastaneleri gibi kapatma pratiğinin mabetleri sayılabilecek kurumların temel işleyişi ıslah etme prosedürüyken, bu süreci daha verimli kılan değişim, kapatılan kişinin kendisi üzerinde bir iktidar uygulamasını sağlamaktır. Hakikat rejimlerinin marjinal olarak işaretlediklerini normalleştirilmiş öznelere çevirmenin en verimli yolu olan panoptikon (Panopticon) modeli bu düzeyde devreye girer.

Foucault, panoptikon fikrini, faydacı liberal düşünür Jeremy Bentham'dan ${ }^{8}$ almıştır. Panoptikon tasarımı Bentham'dan önce gelse bile, ona en olgun halini veren isim liberal teorisyenin kendisidir. Bütünlük anlamına gelen "panoptikon", kelime anlamı olarak da büyük önem taşımaktadır. Panoptikon tipi bütünlük, insana ve topluma dair karanlık noktaları görebilmeyi sağlayan bir bütünlüktür. Buna paralel olarak panoptikon, gözetleme sorunlarını çözen bir iktidar teknolojisidir. Panoptikte her mahkûm, bir kişi ya da birtakım kişiler tarafından gözetlenir. Esas olan bakıştır ve aynı zamanda bir buyruk olarak sözdür (Foucault, 2015b: 87-105). Foucault'nun kendi ifadesiyle panoptikon, "Işığa karşı bir daire içinde düzenlenmiş bireylerin kapatıldığı bir dizi hücreyi izleyen, merkezi bir kulesi olan bir inşaat projesidir. Merkezden, her şey ve her hareket gözükmeden kontrol ediliyor." (2001a: 1597). Burada iktidar ortadan kaybolmuştur, kendisini göstermemektedir, fakat vardır. Düşünür devamında Panoptikon modeliyle Bentham'ın spesifik olarak hapishaneyi düşünmediğini belirterek, bir Fransız icadı olan ve çok çabuk tüm Avrupa yönetimlerini cezbeden "polis"in panoptikonun ikizi olduğunu ekler.

Böylece modern iktidar, kendi antagonizmasını kendi içinde yaratır. Bilgiyi yaratırken, arzuyu ve zevki kışkırtırken güvenlik ve disiplin duvarlarını ince ince örmektedir. Tüm bu disiplin

\footnotetext{
${ }^{8}$ Mimari olarak Panoptikon dairesel bir binadır. Tutukluların hücreleri binanın çeperinde, birbirleriyle iletişim kurmalarını engelleyecek şekilde ayrılmıştır. Gözetleme locası tam merkezde yer alır. Hücreleri aydınlatmak için her hücrede gözetmenin işini de kolaylaştıracak pencereler bulunur. Tutukluların diğer tutukluları görememesi için aralara bölüm duvarları inşa edilmiştir. Hücrelerin yükseklikleri de mahkûmların birbirlerini görmelerini engelleyecek seviyede tasarlanmıştır. Mahkûmlara sürekli olarak çalıştıkları ve düzene ayak uydurdukları müddetçe serbest kalabilme ihtimalleri hissettirilmektedir. Tüm bunların yanında müfettişlerden, memurlardan, yargıç komitelerinden oluşan geniş bir bürokrat takım ve bunların masrafları da hesap edilmektedir. Hastaneler, fabrikalar, okullar, tımarhaneler için de hapishane modeli kullanılabilmektedir. Hapishaneler tüm bunları içeren öncül bir model olarak nitelendirilebilir. Gözetleme ilkesi ilk olarak hapishanelere uygulansa da giderek akıl hastanelerinde, sonra hastanelerde ve okullarda uygulanmaya başlanmıştır (Bentham, 2008: 14-67).
} 
ve güvenlik duvarlarının tuğlası ise yaratılan yalın hakikattir. Yalın hakikatin dayandığı temel izleği oluşturan mekanizma ise hukuk olacaktır.

\section{Michel Foucault Düşüncesinde Hukuk-iktidar İlişkisi}

Foucault'nun felsefi dizgesinde hukuk-iktidar ilişkisine dair tutarlı bir içerik bulunmaz. Nitekim düşünür bir hukuk uzmanı da değildir (Topuzkanamış, 2009: 1833). Daha çok iktidarın tarihini yapısöküme tabi tuttuğu çalışmalarında hukuk, iktidar bağlamında ve bir iktidar türünün işleyişinde kendisine yer bulur. Tam da bu açıdan düşünürün zihin dünyasında hukukun konumuna dair daha sonra geliştirilen tüm argümanlar birbirlerinden farklı tezler savunsalar da kendilerine uygun kaynak bulabilmektedirler. Foucault'nun hukuka dair analizlerinde temel belirleyici dönüşüm ise premodern dönemden modernliğe geçiş sürecidir (Kılıç, 2014: 184-185).

\subsection{Foucault'da Modern Öncesi Dönem ve Hukuksal-Söylemsel İktidar}

Michel Foucault'nun hukuka dair saptamaları da iktidar ilişkisi çerçevesinde yer alır ve Ortaçağ ile başlayarak 18. yüzyılda bir kırılma yaşayan modern toplumlara ait dönemi kapsar (Koloş, 2016: 225). Bu açıdan modern dönemde hukuku konumlandırmak için modern iktidarı anlamak kadar, onun tarihsel arka planını oluşturan modern öncesi iktidar biçimini anlamak da önem arz etmektedir.

Foucault, "hukuksal-söylemsel iktidar modeli" adını verdiği modern öncesi dönemi, sözleşme temeline dayanan ve devredilip devralınan bir iktidar biçimine gönderme yapan sözleşmeci doğal hukuk dönemi olarak işaretler. Foucault’ya göre siyasal matrisi "sözleşme" olan bu dönem 18. yüzyıl filozoflarının zihin dünyasında kristalize olmuştur (Koloş, 2016: 229). Burada bahsedilen özellikle 16.-17. yüzyılların toplum sözleşmecileri arasından Thomas Hobbes'un Leviathan'ında bütünlüklü haliyle açığa çıkan hükümranlık modelidir. Alan Hunt ise Foucault'da "Klasik Çağ" adını verdiği bu dönemi devletin baskın unsur olduğu ve monarşileri karakterize eden bir dönem olarak tanımlar (1992: 5).

Foucault'ya göre monarşik iktidarlar hukuk formunda ifadelerini bulurlar. Toprağın üzerinde dolaylı ya da dolaysız şekilde kurulmuş egemenliğe, silah kullanmaya, hükümdar-tebaa ilişkilerine bağı ıu iktidar tipi, üniter olarak yapılanan, istencini yasa ile özdeşleştiren ve yaptırım ve yasaklama mekanizmaları ile hareket eden bir iktidar biçimidir (2003: 68). Nitekim Ortaçağ'dan itibaren hukuksal düşüncenin gelişimi krallık iktidarı çerçevesinde gerçekleşmiş, hukuk da kralın iktidarının aracı bir formülasyonda işlev görmüştür. Bahsedilen hukuksal/monarşik iktidar sistemini temsil eden uzam ise kralın bedenidir (Foucault, 2011: 103,142). Öte yandan, monarşilere özgü hukuksal-söylemsel iktidar, suskunluk buyuran, yasak döngüsüne dayalı olarak işleyen negatif bir iktidar formudur. Bu iktidar tipolojisi her zaman itaatle sonuçlanır. İtaat eden hukuksal özne, iktidarın kendine özgü gizliliğine, kökeni ilkesel varoluşa dayandırılmış yasakların negatif, buyurgan ve hukuksal niteliğine itaat eder (Foucault, 2003: 67-68). 18. yüzyıla kadar süren hukuksal-söylemsel iktidar modelinde bedenlerin kullanımında en az efor ve en çok verimlilik niteliğine dayalı ekonomik-performatif bir değerlendirmeden çok, malların ve zenginliklerin sahipliğine dayalı bir anlayış hakimdir. Bedenin ekonomik verimliliğine dönük ilişkiler değil borç ilişkilerinin hukuksallığı, bireylerin bedenine yönelik değil hükümdarın bedenine yönelik toplumsal, kültürel ve ekonomik bir yapı söz konusudur (Koloş, 2016: 250). 
Hukuksal-söylemsel iktidar modelinde 12. yüzyıldan 18. yüzyıla kadar geçen süreçte hukuksal yargılama da temelde gerçekleşen suçu ortaya çıkaran, faili tespit eden ve suçlunun maruz kalacağı yaptırımı belirleyen bir yapıya sahiptir. Ortaçağ hukuku maddi hakikat olarak olayın kendisini aydınlatmaya çalışır. Her suç, hükümrana karşı işlenmiş bir başkaldırı olarak ele alınır, çok az sayıda suçlu ele geçirilir ve cezalar karanlık bir şölen edasıyla ifa edilir. Temel gaye, hükümranın yaralanmış iktidarını mahkûmun bedenini un ufak ederek tazelemek ve tebaa ile ilişkisini sağlamlaştırmaktır. Mahkûmun bedeni, hükümdarın üzerinde damgasını bastığı, iktidarın sonuçlarının işlendiği bir nesnedir (Foucault, 1992: 136). Hükümdarın yaşam ve ölüm yetkisi Patria Potestas kökeninden, yani Romalı aile reisinin, ailesi üzerindeki iktidarından gelmektedir (Foucault, 2003: 99). Ne var ki yaşam ve ölüm üzerindeki iktidar, yaşama gönderme yaparken bile ancak ölüm üzerinden yürütülebilir. Yaşam üzerindeki hak, yalnızca öldürme üzerindeki hakkın kullanımına bağlı olarak görünür kılınabilmektedir. Yaşam ve ölüm ilişkisindeki temel belirleyici düzey ölüm üzerindeki yetkedir (Foucault, 2015c: 246).

Öte yandan hukuksal-söylemsel iktidar modeli ya da hukuksal hükümranlık modeli ile modern biyoiktidar dönemi arasında keskin bir kılıç darbesiyle gerçekleşmiş bir ayrım olmayıp bir eklemlenme söz konusudur (Koloş, 2016: 264). Başka bir deyişle hukuksal-söylemsel iktidar modeli modern dönemde tamamıyla ortadan kalkmamış, modernitenin özneleştirici pratiğinin yanı sıra hukuksal özne, doğal hak ve özgürlüklere sahip kişi olarak Modern Çağ’da önemi azalmakla birlikte bir hukuk öznesi olarak varlığını korumuştur (Koloş, 2016: 253). Ne var ki modern iktidar, temel olarak hukuksal-söylemsel iktidar modeli bağlamında kendini ifade etmez (Valencia-Villa, 1981: 363). Hukuk artık bireyi özne kılan iktidar pratiklerinin "dispositif'i olma noktasında bir önem arz eder.

Bu noktada dispositif kavramını açıklamak gerekmektedir. Dispositif, disipline edici bir nosyon olarak söylemsel ve söylemsel olmayan tüm pratikler vasıtasıyla içselleştirilen iktidar mekanizmalarını ifade etmektedir. Söylemsel pratik denilen şey söylemin bizzat kendisidir. Söylemsel olmayan pratikler ise kurumsal yapılar ve mimari biçimler gibi daha somut pratiklerdir. Foucault, söylemler, kurumlar, mimari biçimler, düzenleyici kararlar, bilimsel, felsefi ve ahlaki önermeler, yasalar, idari tasarruflardan oluşan heterojen bütünü "dispositif" olarak adlandırır. Ona göre dispositifler güç ilişkilerini belirli bir yönde geliştirir ve güdümlerler (Foucault, 2016: 18). Bedensel şiddet uygulamadan bedenin ehlileştirilmesi sağlanır. Hukuksal aygıt da bu bağlamda dispositif olarak değerlendirilir. Böylece modern dönemin dispositiflerinin önemli bir unsurunu hukuk oluşturmaktadır (Koloş, 2013). Dispositif olarak hukuk, bu yönüyle modern tarihsellik içerisinde bilgiden hakikate ve özneleşme pratiklerine kadar iç içe geçmiş bir iktidar tasarımıyla bağlantı içerisinde anlamlandırılmaktadır.

\subsection{Modern Dönem ve Foucault'da Dispositif Olarak Hukuk}

Michel Foucault, kapitalizmin gelişimiyle birlikte bilhassa 18. yüzyılda netleşen yeni bir iktidar tarzından bahsetmektedir. Yaşam üzerine yönelen iktidar biçimi olarak insan türünün biyolojik özelliklerini politik bir stratejinin nesnesi kılan ve öznellik kiplerini dayatan modern döneme haiz bu iktidar perspektifini biyoiktidar (biopouvoir) olarak adlandırır (Koloş, 2016: 266).

Biyoiktidar, nüfus ve sanayi patlaması yaşanan kapitalist çağda hukuksal-söylemsel iktidar biçiminin, ekonomik ve politik süreçleri kontrol edememesi hasebiyle ortaya çıkmış ve insan 
birikimini sermaye birikim süreçlerine uygun kılmıştır (Foucault, 2003: 104). Hükümdarlığın hükmeden ama yönetmeyen biçimi yerine daha az hükmeden ama daha çok ve verimli yönetmeye kadir bir iktidar formülasyonuna geçilmiştir. Ekonomik-performatif bir iktidar tasarımı olan biyoiktidarın unsurlarından ilki 17. yüzyılın sonlarında ortaya çıkan ve bedene makine gibi yaklaşan, onu terbiye eden, hizaya sokan, yeteneklerini artıran, güçlerini açığa çıkaran bedenin "politik anatomi (anatomie politique)"sidir (Foucault, 2003:102). Bedene odaklanmış iktidar teknik ve stratejilerinin disiplinci mekanizması politik anatomiye denk düşmektedir (Foucault, 2015c: 269). İkinci unsur, 18. yüzyılda oluşmaya başlayan ve insanı bedensel olarak ele alan politik anatomi dışında insanı bir tür olarak ele alan; doğum, ölüm oranları, yaşam istatistikleri, konut talepleri, sağlık düzeyleri gibi disiplinci değil düzenleyici ve denetleyici mekanizmalar bütünü olan nüfusun biyopolitiğidir (Foucault, 2003: 102-103). Politik anatominin uzamı beden iken, biyopolitiğin üzerinde işlem yürüttüğü alan nüfus olarak belirir. Nüfus ile ilgili bir müdahale alanı olan biyopolitikte güvenlik unsuru baskın gelmektedir. Beden disipline edilirken nüfus düzenlenme noktasında mevzilenir. Düzenleme, bir güvenlik hususu olarak karşımıza çıkar. Güvenlik problematiği biyopolitiğe içkin olması açısından disiplinci politik anatomiden ayrılır (Foucault, 2013: 20-41). Nüfusun yönetimselliğini ihtiva eden biyopolitiğe içkin bir kavram olarak güvenlik, tehlike nosyonu üzerinden toplumsal düzeni mümkün kılar (Çalkıvik, 2011: 24). O halde Foucault'ya göre elimizde beden-organizma ve disiplinden oluşan kurumlar dizisi ile nüfus, biyolojik süreçler ve düzenleyici mekanizmalardan oluşan yönetimsel rasyonaliteye dayalı bir devlet dizisi bulunmaktadır (Foucault, 2015c: 256). İşte tam bu noktada 18. yüzyıldan itibaren hukukun yavaş yavaş mutasyona uğradığı görülmektedir. Ortaçağın hukuksal nitelikli devleti, yerini yönetimsellikle rezonans halindeki hukuka bırakmıştır.

Böylece karşımızda modern dönemde hukukun yerinin tespitine dair bir problem belirir. Foucauldian literatürde modern dönemde hukuka dair üç farklı yaklaşım ortaya çıkmaktadır. "Hukukun defedilmesi" (expulsion of law) ${ }^{9}$ tezi 1994 yılında ortaya atılmış ilk yaklaşım olarak karşımıza çıkar. Bu yaklaşıma göre Foucault hukukun modern dönemdeki rolünü düşünmemiş ya da onu kasten marjinalleştirmiştir. Hunt'a göre Foucault açısından modern dönemde hukukun altı oyulmuştur. Hukukun defedilmesi yaklaşımı Foucault stratejisinin bir etkisidir. Onun iktidara dair tartışmasında modern dönemin iktidar biçimi hukukun yerini almıştır. Hunt'a göre Foucault için modern iktidar monarşik iktidarın yerini aldıkça hukuk, pre-modern bir nosyon olarak defedilmek durumunda kalmıştır (1992: 2-6). Defetme tezi içerisinde diğer önemli eğilimi temsil eden Ben Golder ve Peter Fitzpatrick ise Foucault'nun modern iktidarında hukukun defedildiği yönündeki tezi iki alt başlıkta analiz ederler. Illk olarak hukukun modern dönemde öneminin oldukça azaldığı bir bakış açısını belirtirler. İkinci olarak ise hukukun, disiplinci anatomi-politik ile düzenleyici biyopolitik ya da yönetimsellik dizgelerinin yarattığı öznellik kiplerinin işleyişi bağlamında bir enstrüman haline geldiği, hukukun basitçe gasp edilmediği fakat modern iktidar açısından uyumlu bir parçaya dönüştüğü yönünde bir uslamlama yürütürler (Golder ve Fitzpatrick, 2009: 242). Gerald Turkel'e göre de hukuksal-söylemsel iktidar modeli, devleti ve hukuksal

\footnotetext{
${ }^{9}$ Detaylar için bkz. : Hunt A., Wickham G., Foucault and Law: Towards a Sociology of Law as Governance, Londres, Pluto Press, 1994.
} 
kurumu temel yapılar olarak merkezileştirdiği için iktidar ve hukuk analizini sınırlayan bir modeldir. Zira Foucault, modern iktidarı çoklu, merkezsiz, bilginin ve sosyal yapıların üretimi olarak kavramsallaştırır. Bu bağlamda hukuk modern dönemde defedilmiştir (1990: 170).

Defetme tezinin karşısında "Foucault'nun Hukuku" (Foucault's law) tezi yer almaktadır. Bu yaklaşıma göre Foucault, hukuku modern dönem içerisinde defetmemiş, hukuk ve disiplin arasında bir eklemlenme ve etkileşim olduğunu öne sürmüştür (Golder ve Fitzpatrick, 2009: 2829). Modern dönemde hukuk halen etkili bir öğedir. "Foucault'nun Hukuku" tezi "ilişkide hukuk" (law in relation) konseptine başvurur. Bu bakış açısına göre hukuk hem kendi dışındaki iktidara dayanır hem de bu iktidarlar hukuk aygıtına yaslanırlar. Öyle ki disiplinci iktidar, değil hukuku defetmek baştan sona hukuka bağlıdır. Bahsedilen teze göre disiplinler, kurulma aşamasında hukuka bağlıdırlar ve hukuk sayesinde kurulurlar (Golder ve Fitzpatrick, 2009: 70-85). Başka bir ifadeyle, Foucault'nun düşünsel sisteminde hukuk, disipliner iktidarın kurulması yolunda taşları döşemiştir. Öte yandan hukuk, disiplinci iktidarın hizaya getiremediği kesimleri ve disipline olmama potansiyeli olanları belirli bir toplumsal kalıba dökerek uysallaştıran uğraklardan biri olmuştur. Böylece disipline edici iktidar hukuka bağlı biçimde ortaya çıkar. Bu durum karşılıklı, çok yönlü ve dinamik bir ilişkidir (Golder ve Fitzpatrick, 2009: 71-100). Foucault'nun Hukuku" tezinde hukuk, modern toplumların işleyişinde meşrulaştırıcı ve itaati sağlayıcı özellikleri bakımından da yorumlanmaktadır. 17. yüzyılın politik anatomisi ve 18. yüzyılın biyopolitiği işleyiş mekanizmalarını gizlemek gerektiğinde hukuka başvurmuşlardır. Bu noktada, iktidarın tahakküme varacağı sınır aşıldığı an devreye girecek olan hukuk aygıtı gerekli kılınmaktadır (Foucault, 2011: 114). Düşünüre göre modern toplumda hukukun varlığını sürdürmesini gerekli kılan faktörlerden biri biyoiktidarın tahakküm etkilerini maskeleyen ve itaati mümkün kılan bir özellik ihtiva etmesidir (Koloş, 2016: 301).

Üçüncü ve son yaklaşım olarak çalışmanın da temel perspektifini oluşturacak olan modern dönemde hukukun pozisyonunu tespit eden "dispositif olarak hukuk" tezi mevcuttur. Esasen bu noktaya kadar aktarılan "Defetme Tezi" de "Foucault'nun Hukuku" tezi de kendilerine Foucault'nun kuramsal altyapısı açısından kabul edilebilir bir alet çantası bulsalar da her ikisi de bazı problemler barındırmaktadır. "Defetme Tezi", hukuku tüm tarihsel dönemlerden soyutlanmış bir değişmezlik içerisinde ve tarihsellikten ayrıksılık çerçevesinde değerlendirmektedir. Hukuku modern dönemde tamamen yadsıyarak problemli bir perspektif sunar. "Foucault'nun Hukuku" tezi ise modern dönemde zorunlu ve tamamıyla saf bir hukuksal varlıktan yana tavır takınarak bu kez de iktidar ilişkileri açısından nispeten daha sınırlı bir bakış açısını yansıtmaktadır. Son yaklaşım olan "dispositif olarak hukuk" bakış açısı, çalışma açısından da Foucault'nun genel teorik şeması açısından da daha belirgin bir konum iştigal eder.

Daha önce de belirtildiği üzere dispositif, söylemsel ve söylemsel olmayan unsurların oluşturduğu heterojen, işlevsel ve ilişkisel bir bütündür. İktidar ilişkilerini belirli yönlerde güdümleyen bir ağdır. Bir rasyonaliteye hizmet eden ve genel olarak stratejik olan dispositifler birbilerini meşrulaştırır ve koşullarlar (Agamben, 2012: 15-16). O halde Foucault'da modern dönem için hukukun konumlanışı, iktidar-bilgi bağıntısında yönlendirici, meşrulaştırıcı bir pozisyona oturan, öznellik kipleriyle entegre biçimde işleyen bir dispositif olarak kabul edilebilir. Başka bir deyişle, dispositif olarak hukuk, özne-hakikat ilişkilerinin modernitede büründüğü tarihsel konumdur (Koloş, 2016: 311). Böylece karşımıza çıkan şemada, "Defetme Tezi”nde olduğu gibi hukukun 
tamamıyla etkisini kaybettiği değil; daha çok norm lehine gündemden düştüğü bir durum söz konusudur. Foucault, modern toplumsal formasyon açısından yasa ile norm arasında bir ayrım yapmaktansa onları derceder (Neocleous, 1996: 68).

Norm ile yasanın bütünleştirildiği kavrayışta, cezai müeyyide yine uygulanır ancak esas gaye yasadışılık potansiyelini ortadan kaldırmak, suçluyu ıslah ve terbiye etmek, suça eğilimi terbiye ederek normalleştirmektir. Toplum artık savunulması gereken bir uzam haline gelir. Tehlikelilik nosyonu modern toplumun kalbine yerleşir ve hukuk, yasa ve yasa ihlali üzerinden değil; bireyleri dönüştürme stratejisi üzerinden işler (Foucault, 2015a: 220-223; 2015b: 186-198). Psikiyatri ya da adli tıp başlığı altında hukuk merciine dâhil edildikçe kişiden bilgi kopartarak ondaki hakikati devşirmeye, öte yandan ona bir hakikat rejimi dayatmaya varan hukuk-iktidar-hakikat üçgeni oluşturulur. Yasaya tabii olmak hakikate tabii olmaktır ve yargıya kendimizi itiraf ettikçe hakikati üretir, insan bilimlerinin hakikat oyununa dâhil oldukça da hakikat üretiminin nesnesi kılınırız. Bize dayatılan öznellik kiplerinin içerisinde tabiiyet konumları da bizi özne kılar. Hukukun bu süreçteki işlevi oldukça açıktır (Foucault, 2011: 102-103). Bu pratikler içerisinde mahkûm yalnızca işlediği suçu değil, kendisini itiraf etmeye zorlanır (Koloş, 2016: 325). Böylece hukuk da bireyi biçimlendirme noktasında iktidar-bilgi korelasyonu düzeyinde diğer söylemlerle birleşir (Turkel, 1990: 170). Jerry D. Leonard ise hukuku, pozitif iktidarın üretkenliği bağlamına oturtur ve iktidarın bilgiyi ürettiği gibi bilgi-iktidar formunun söylemsel bir aygıtı olan hukukun da benzer biçimde bilgiyi ürettiğini belirtir. Böylelikle hukuk da bir hakikat rejimi oluşturur. $\mathrm{O}$, bir hakikat makinesidir (Leonard, 1990: 11-12). Özetle, dispositif olarak hukuk, modern bilimler ile kombinasyona girmek suretiyle özne ve hakikat üretimini mümkün kılan bir aygıttır. Hukuk da iktidar da aynı siyasal rasyonalitenin dispositifsel parçalarından ibarettir (Koloş, 2016: 351).

Son olarak, dispositif olarak hukuk tezinin diğer tezlere göre Foucauldian düşünceyi daha iyi yansıttığı ve çalışmanın ilerleyen kısımlarında görüleceği üzere 12 Eylül konjonktüründe hukukiktidar ilişkisine dair daha açıklayıcı bir işleve sahip olduğu düşünülmektedir.

\section{12 Eylül Darbesi ve 1982 Türkiye Cumhuriyeti Anayasası}

Foucauldian bir perspektifle Türkiye siyasal yapısına ve daha özel olarak ise iktidar ilişkilerine bakıldığında ordunun bu iktidar ilişkilerinde önemli bir rolü olduğu görülmektedir. Türkiye Cumhuriyeti'nin her daim ordu-millet özelliğiyle var olagelmiş bir devlet yapısı ve teşkilatı vardır. TSK Türkiye'de rejimin kurucu ideolojisinin aslî taşıyıcısı, Kemalizm'in politik bir ideoloji olarak benimsetilmesinde temel işlev gören yapı olmuştur (Cizre, 2004: 135). TSK özellikle militarist etkilerin yayılmasında başat faktör olarak kendini gösterir. Militarizm, askeri kurumsallaşmadan hareket ederek silah, üniforma, disiplin ve baskıyı çağrıştıran iç yapıda homojen, tutarlı ve rasyonel bir gücü temsil eder. Böylece dışarıya karşı da bir tehdit ve kurtarıcı rolüne bürünmüştür (Mahçupyan, 2002: 50). Söz konusu “kurtarıcı rol”"10, TSK'nin müdahaleleri olarak tezahür etmiştir.

\footnotetext{
${ }^{10}$ TSK politik müdahalelerinde halktan yana kitlesel bir mukavemet ile karşılaşmamışsa da bahsedilen müdahalelerde bütünüyle rıza ürettiği de söylenemez. Süreç içerisinde de TSK'nın siyasal alandaki rolü ile ilgili zihinsel bir değişim haritası dikkat çekmektedir. 2000'lerin başından itibaren askerin iç politikadaki müdahalelerine yönelik toplumsal açıdan gelişen bir değişim söz konusudur. Avrupa Birliği (AB) ile uyum süreci ve bu minvalde TSK'nın imtiyazlarını azaltan reformlar neticesinde TSK'nın politik rolü sınırlandırımıştır (Gürsoy, 2014: 161-162). Metinde bahsedilen "kurtarıcı rol” misyonu ise hem kendi bağlamı içerisinde baskın politik güç olarak hem de Türkiye siyasasında süregelmiş toplumsal ve politik elit olarak TSK'nın genel karakteristiğini nitelemektedir.
} 
Bahsedilen müdahalelerin üçüncüsü olan 12 Eylül darbesinin arifesindeki toplumsal ve siyasal atmosfere bakıldığında, sürecin her açıdan bir sıkışıklık taşıdığı şüphe götürmez. Süreç boyunca toplumsal kargaşanın, özellikle Milliyetçi Cephe koalisyonlarının bir "cephe" olmasından ileri gelen siyaset paradigmasının toplumsal yankılarının, komünizm düşmanlığıyla harlanan paramiliter faaliyetlerin ve sağ-sol ideolojik mücadelelerinin yarattığı faili meçhullerin kaotik bir manzara sunduğu görülmektedir. 1977'den itibaren milliyetçi-ülkücü paramiliter gençlik hareketi kanlı eylemlere başlamış, Dev-Sol hareketi de buna karşılık benzer eylemlerini artırarak devam ettirmiştir. Bu süreçte, o tarihlerde henüz Orgeneral olan ve emekliliğini bekleyen Kenan Evren'in önü beklenmedik biçimde açılmış, önce Kara Kuvvetleri Komutanlığı'na, ardından 7 Mart 1978'de Genelkurmay Başkanlığı'na atanmıştır. III. Ecevit Hükümeti, derinleşen iktisadi bunalımı, artan şiddet ve cinayetleri önleyemez olmuştur. Birçok ilde yaygınlaşan sıkıyönetime rağmen, Sivas olaylarında Alevi mahallelerine saldırılarak 12 kişi öldürülmüş, Bahçelievler Katliamı ile Türkiye İş̧̧i Partili (TiP)'li 6 genç katledilmiştir. Bu durumu 1978 yılı boyunca üniversite hocalarına yönelik cinayetler, Maraş katliamı ve Abdi İpekçi cinayeti izlemiştir. Nihayet Ecevit hükümeti zayıflayarak güç kaybetmiş ve 1979 ara seçimlerinde Demirel'in azınlık hükümeti göreve gelmiştir. Demirel hükümeti de toplumsal barış bağlamında başarılı olamamış ve Türkiye; Çorum olayları, eski Başbakan Nihat Erim'in suikasta uğraması, Devrimci İşçi Sendikaları Konfederasyonu (DiSK) eski Genel Başkanı Kemal Türkler'in öldürülmesi ve Gün Sazak cinayetleriyle hızla darbe atmosferine girmiştir. Bu süreç içerisinde tam 160 oylamaya rağmen cumhurbaşkanlığı seçimlerinin uzun süre sonuçlanamamış olması da darbe sürecine giden son dönemeç ve darbe rejimine meşruiyet üreten hadise olarak göze çarpmaktadır (Aydın ve Taşkın, 2014: 289-316).

Askeri darbe ile beraber ilk günden itibaren hakikat üretiminin etkilerinin göze çarpmaya başladığı görülür. Örneğin 13 Eylül 1980 tarihli Milliyet Gazetesi kapağına "Ordunun yönetime gelmesi dışta olumlu karşılandı" başlığını atmıştır (Milliyet, 13 Eylül 1980). Burada hakikat etkileriyle iç içe geçmiş bir söylemin ilk etkileri görülebilmektedir. Öte yandan Kenan Evren'in devlet televizyonu TRT'ye verdiği demeçte de yeni bir söylemsel pratik enformasyon aygıtlarında dolaşıma sokulmuştur:

\section{"Aziz yurttaşlarım;}

(...) Silahlı Kuvvetler Aziz Türk milletinin hakkı olan refah ve mutluluğu, vatan ve milletin bütünlüğü ve gittikçe etkisi azaltılmaya çalışılan Atatürk ilkelerine yeniden güç ve işlerlik kazandırmak, kendi kendini kontrol edemeyen demokrasiyi sağlam temeller üzerine oturtmak, kaybolan devlet otoritesini yeniden tesis etmek için yönetime el koymak zorunda kalmıştır.

\section{(...)}

Her zaman milletiyle bir bütün ve Türk milletinin emrinde olan Türk Silahlı Kuvvetlerine ve yeni yönetime karşı yapılacak her türlü direniş, gösteri ve tutum anında en sert şekilde cezalandırılacaktır" (Resmî Gazete, 12 Eylül 1980). ${ }^{11}$

Evren tarafından dolaşıma sokulan söylemde "Kendi kendini kontrol edemeyen demokrasiyi sağlam temeller üzerine oturtmak", "Türk milletinin hakkı olan refah ve mutluluğu sağlamak" adı altında dayanak olarak ortaya koyulan misyon, askeri yönetimin söylem ve hakikatle iç içe

\footnotetext{
${ }^{11}$ Konuşmanın tamamı için bkz. “Genelkurmay ve Millî Güvenlik Konseyi Başkanı Orgeneral Kenan Evren'in Türk Milletine Açıklaması", T.C. Resmî Gazete, 12.09.1980, https://www.resmigazete.gov.tr/arsiv/17103 1.pdf (Erişim: 29.07.2020).
} 
geçtiğini göstermektedir. Hemen arkasından gelen "Yeni yönetime karşı yapılacak her türlü direniş, gösteri ve tutum anında en sert şekilde cezalandırılacaktır" ifadesi de söylem ve hakikatle iç içe geçmiş iktidarın disiplin ilkesini gözler önüne sermektedir. Süreç ilerledikçe 12 Eylül iktidarı yeni anayasa için de çalışmalarını hızlandırmıştır. Kenan Evren bu hususta yeni anayasanın nasıl olmaması gerektiğini, önceki anayasaya istinaden 1982 Ağustos'unda Afyon'da yaptığı konuşmada dillendirmiştir. "O anayasa bize bol geldi, içinde oynamaya başladık, oynaya oynaya 12 Eylül'e geldik" ifadesinde de görüleceği gibi artık hedef 27 Mayıs Anayasası'nın sunduğu özgürlüklerdir (Aydın ve Taşkın, 2014: 333-334). Böylece yeni anayasa çalışmaları yapıııken özgürlüklerin kapsamı ve güvenlik ilkesi doğrultusunda değişikliklere gidileceği açıkça görülmektedir. Yeni anayasa çalışmalarına başlandığında demokratik kitle örgütleri ve partiler öneride bulunmazken üniversitelerden raporlar istenmiştir. Sivil toplum örgütleri ve siyasiler, anayasa taslağının hazırlanmasında tamamen dışlanmışlardır. Hatta yeni anayasa taslağını eleştirmek dahi yasaklanmıştır. Anayasa referandumu sürecinde en çok eleştirilen maddeler ise Evren'e "evet" ile anayasaya "evet"i birleştiren maddeler olmuştur (Ahmad, 1995: 263). Orgeneral Evren'in "evet" oyu lehinde verdiği nutukların eleştirilmesinin dahi yasaklandığı halkoylaması \%91,4 lük bir oranla kabul edilse de (Zürcher, 1995: 410) dönemin hukukunun iktidar ilişkileri açısından nasıl bir pozisyon aldığına dair derin izler bırakmıştır. Bu noktada, Foucault'nun yasaya ve daha genel olarak hukukun işlevine dair düşüncelerinin, 1982 Anayasasının henüz kabul edilme sürecindeki iktidar baskısıyla birlikte düşünülmesi Foucauldian açıdan hukuk iktidar ilişkisinin 12 Eylül dönemindeki haritasını ortaya koymak açısından önemlidir.

\section{Anayasal Hak ve Hürriyetlerin Sınırlandırılması Bakımından Dispositif Olarak 1982 Ana- yasası}

Modern dönemde hukukun dispositif olarak yerini tespit ederken Foucault, yasanın normlaştığı bir toplumdan bahsetmekteydi. Bu noktada normu, esasen kural olarak benimsenmiş bir olguyu ve yerleşmiş bir ilkeyi, "normal" olanı ve hakikati ortaya koyan prosedürler bütünü olarak görmekteyiz. Modern toplumda yasa arka planda ve iktidar ile entegre biçimde norm halini almıştır. Belirli bir sınırlandırmaya giden yasanın en son noktası ölümdür. Ancak nesnesi yaşam ve beden olan iktidarın denetim ve gözetim ilkelerine daha çok ihtiyacı vardır. Bu anlamda ön planda olan mekanizma, denetleme ve gözetleme mekanizmasıdır; fakat yasa da tamamen ortadan kalkmamıştır. Yasa artık bir norm gibi görev yapmaktadır (Foucault, 2016: 17-18). Başka bir deyişle normlar, disipline edici pratiklerin davranışlarda içselleştirildiği ortak standartlarla birlikte ele alınır. Bahsedilen uygun davranış standartları, uygun olmayan ve hizadan sapmış davranışları düzeltmek amacıyla dizayn edilmişlerdir (Hunt ve Wickham, 1994: 49).

Biyopolitika düzlemi ile norm kavramının doğrudan bağlantısı söz konusudur. Norm, toplumsal işleve sahip, nüfusu yönetmekle ilgili olacak şekilde idari mekanizmalara eklemlenmiş bir tür "kararlar bulutu"dur Normalleştirme toplumu bu bağlamda hem bedenin hem de nüfusun denetlenmesi noktasında işlev gören normun bedene ve nüfusa sirayet ettiği toplum modeli olarak sunulur (Koloş, 2016: 277). Öte yandan Foucault, normun bedensel yönünün de altını çizer. Norm, hem bedeni hem nüfusu normalleştirir. Normalleştirme toplumu da disiplinin normu ile düzenlemenin normunun çakıştığı toplumdur (Foucault, 2015c: 258).

Bu noktada 1980 darbesinin ardından oluşturulan toplum modelinin norm toplumuna ne ölçüde örnek teşkil ettiğinin ve askeri iktidarın toplumsal kesimlere yönelik tehlikelilik nosyonunu kullanarak disipline edici biyoiktidar uygulamalarını ne ölçüde hayata soktuğunun ince- 
lenmesi gerekmektedir. Bahsedilen incelemede iktidar ile ilişkisi bakımından hukukun da irdelenmesi ve dispositif olarak işlerliğinin soruşturulması gerekmektedir. Bu soruşturma yapılırken 12 Eylül'ün hukuksal anlamda kimliği olan 1982 Anayasasının ruhuna bakmak ve onu haklar ve hürriyetler bakımından incelemek hukukun iktidar ilişkilerindeki konumunu tespit etmek açısından zaruridir. Bu açıdan Türkiye Cumhuriyeti'nin daha önceki anayasal deneyimleri göz önünde tutularak 1982 Anayasası'nın niteliğinin saptanmasında karşılaştırmalı bir değerlendirme yerinde olacaktır.

1923 yılında Cumhuriyetin ilanının ardından oluşturulan ilk anayasa olan 1924 Anayasası Fransız Devrimi'ndeki zihinsel içeriğe benzer biçimde özgürlüğü başkalarının özgürlüğünün sınırlarında sabitliyor ve kısıtlıyordu. Ahmet Mumcu'ya göre 1924 Anayasası devletçi yani otoriteden yana değil liberal ve bireyci bir nitelik taşıyarak, liberalleşmenin, demokrasi ve özgürlüğün önünde engel olmamıştır (1986: 397-398). 1961 Anayasası $^{12}$ ise devletin erkleri arasında bir denge mekanizması, anayasal üstünlük, demokratik hukuk devleti ve kuvvetler ayrılığı şiarını benimsemiştir. Bununla birlikte 1961 Anayasası ile birlikte ifade özgürlüğüne de güvence sağlanmıştır (Birol, 2012: 40-43). Süreç içerisinde 1968 öğrenci hareketlerinin ulusal düzeydeki etkilerinin bir sonucu olarak 1971 müdahalesi ile liberal anayasal haklar ve hürriyetler budanmış, bir denge fren mekanizması ortaya çıkmıştır. 12 Eylül müdahalesi ve ardından 1982 Anayasası ile yürütme erkinden yana daha yoğun bir ağırlık barındıran siyasal-hukuksal atmosfere geçişle neticelenmiştir. 1982 Anayasası, siyasal anlamda liberal özgürlükçü bir demokrasiyi kendisi ile özdeşleştirmemiştir (Tanör, 2019: 118).

Bu açıdan 1982 Anayasası, Osmanlı'dan Cumhuriyete bakiye kalan tüm süreç boyunca süregelen anayasal gelişme dinamiğinin karşıtı bir çerçevededir. ${ }^{13}$ Bülent Tanör'e göre, gerek 1876 Kanun-i Esasi'sinin monarşiyi sınırlayan özelliği, gerek 1961 Anayasasının despotik idareyi tasfiye edip demokratik kurumsallaşmayı genişletmesi türünden bir özellik 1982 Anayasasında görülmez. Bu bağlamda 1980 müdahalesi ile birlikte otoritenin ve devletin güçlendirilmesi noktasında açık seçik bir eğilim görülmektedir (2019: 87). Bunun yanında, anayasayı oylayanın referandum aracılığıyla halkın bizatihi kendisi olduğu söylenebilir. Ne var ki 1982 Anayasasının büyük çoğunlukla kabulü, sahih bir mutabakatın varlığını göstermez. Daha çok bir evetleme/hayırlama operasyonu olarak tanımlanabilecek anayasa referandumu, bilim terminolojisi perspektifinden bir plebisitten öteye geçmez (Tanör, 2019: 97). Kemal Gözler'e göre referandum bir metni oylamak anlamına gelirken plebisit bir ismi oylamak anlamına gelmektedir. Bu açıdan Gözler, plebisiti baştan çıkarılmış bir demokrasi, halk katılımı olmaksızın hazırlanan anayasa tasarısının dar bir özgürlük ortamında halka dayatılması olarak anlamlandırmaktadır (2017: 2-4).

Bahsedilen dar özgürlük ortamında oluşturulan 1982 Anayasası hak ve hürriyetler bağlamında ele alınırken özellikle bahsedilen anayasal hak ve hürriyetlere değinen maddelere göz

\footnotetext{
12 Kemal Karpat'a göre 1961 Anayasası'nın niteliği "halkçı demokrasi" ile "yukarıdan yönetilen demokrasi" arasındaki farkta somutlaşmaktadır. 1961 Anayasası yeni bir devlet felsefesi oluşturarak belirli sosyal grupların çıkarlarını, tutum ve düşüncelerini karşılıklı olarak ifade etmelerine olanak tanıyan dengeli bir siyasal/toplumsal düzen kurmaya gayret göstermiştir (2010: 56-73). Öte yandan bu denge ve kontrol mekanizması, yönetime yeni ortaklar sokarak vesayet kurumlarını da oluşturmuştur. 1961 Anayasası'nın getirdiği Anayasa Mahkemesi, Yargıtay, Danıştay, Askeri Yargıtay, Uyuşmazlık Mahkemesi, Yüksek Hâkimler Kurulu gibi kurumlar bunlar arasındadır (Aydın ve Taşkın, 2014: 91).

${ }^{13}$ Bahsedilen tarihselliğin detaylı okuması için bkz. Tanör, Bülent (2018). Anayasal Gelişme Tezleri, İstanbul: Yapı Kredi Kültür Sanat Yayıncılık.
} 
atmak gerekmektedir ${ }^{14} .1961$ Anayasası'nın 2. maddesinde Türkiye Cumhuriyetinin "insan haklarına başlangıçta belirtilen temel ilkelere" (Resmî Gazete, 1961) dayalı oluşu hiçbir kayda bağlanmamışken, 1982 Anayasasının 2. maddesinde "insan haklarına saygılı" Iığın, "toplumun huzuru, milli dayanışma ve adalet anlayışı içinde" kalmak ve bahsedilen sınırları aşmamak şartlarına bağlandığı görülür (Resmî Gazete, 1982). Bu açıdan 1982 Anayasası, "insan haklarına saygı” ilkesini "demokratik hukuk devleti" ilkesiyle dengelerken, bahsedilen dengeleme ve sınırlama düzeyini belirleyecek hakikati, iktidar ilişkisi içerisinde oluşturup düzenleyebileceği bir açıklık bırakmaktadır.

1982 Anayasasının 7. paragrafında belirtilen “Hiçbir düşünce ve mülahaza Türk milli menfaatlerinin, Türk varlığının Devleti ve ülkesiyle bölünmezliği esasının, Türklüğün tarihi ve manevi değerlerinin, Atatürk milliyetçiliği, ilke ve inkılapları ve medeniyetçiliğinin karşısında korunma göremez" ifadesi, düşüncenin sınırlanacağı noktaları işaret etmektedir. Oysa düşünce özgürlügünün sınırlarını belirten tüm bu örnekler topluma potansiyel bir tehdit olarak yaklaşan bir iktidar ilişkisi kapsamında tayin edilen hakikatlerdir. Ertuğrul Mavioğlu, yargılandığı dönemde 12 Eylül hukukunu düşünce suçları kapsamında anlatırken şunları aktarmaktadır:

"Iddianamede aklımda kaldığı kadarıyla düşünce suçu da garip bir şekilde tanımlanıyordu. Öncelikle düşünce iyi ve kötü, zararlı ve zararsı diye tasnif ediliyor ve suç tanımı şöyle sürdürülüyordu: "Düşünce kafada kaldığı sürece anayasamıza göre suç sayılmaz. Düşünce açıklandığı zaman tabii ki suçtur." (2006a: 62).

Mavioğlu'nun ifadelerine ek olarak, 85 bin kişinin yalnızca düşünce suçundan yargılandığı, anayasadan ayrı olarak Türk Ceza Kanunu (TCK)'nın 141. ve 142. maddeleriyle sosyalist ve komünist örgütlenmeye dâhil olma ve komünizm propagandası yaparak "milli duyguları zayıflatma" gibi suçların genel-geçer bir gerekçe haline dönüştürüldüğü (Öndül, 2007) 12 Eylül sürecinde anayasal hak ve hürriyetlerin hukuk-iktidar-disiplin bağlamında ve özellikle tehlikelilik nosyonu üzerinden kısıtlandığı bir normalizasyonun izleri görülebilmektedir.

Yine temel hak ve hürriyetler bakımından 1982 Anayasasının 8. paragrafında, "Her Türk vatandaşının (...) onurlu bir hayat sürdürme ve maddi ve manevi varlığını bu yönde geliştirme ve anayasadaki temel hak ve hürriyetlerden yararlanabilme hak ve yetkisi de milli kültür çerçevesi içinde kalınması şartına bağlıdır" (Resmî Gazete, 1982) ifadesinde somutlaştığı görülen temel hak ve hürriyetlerden yararlanma koşulu, "milli kültür"e bağlıık eksenine oturtulmuştur. Lütfi Duran'a göre de temel hak ve özgürlüklerin genişletilmesi değil sınırlılığının esas olduğu, devlet ve toplum yararının ise öncelikli ve üstün tutulduğu görülebilmektedir. Anayasa, fikir, inanç ve kararlarının anlaşıımasını, kendisine mutlak saygıyı ve sadakatle uygulanmayı talep etmektedir (1984: 11). Bu açıdan anayasanın, "hürriyetçi demokrasi” anlayışını mümkün olabilecek en dar kalıplar içerisinde ele aldığı söylenebilir (Tanör, 2019: 120). Bu durumda bu dar kalıplar içerisinde ele alınan hürriyetçilik ve demokrasi tanımlamalarıyla daha geniş ve uç hürriyetçilik ve demokrasi konseptleri aynı kavrama gönderme yaparken farklı içerikler sunarlar. Demokrasi

\footnotetext{
${ }^{14} 1982$ Anayasasının incelenecek maddelerinin belirlenmesindeki selektif tutumun gerekçesi "temel hak ve hürriyetler" mefhumudur. Bu açıdan Türkiye'nin anayasal gelişim dinamiğinde ve 1982 Anayasasında hak ve hürriyetler nosyonu Foucauldian analiz hususunda temel kriter olarak belirlenmiştir.
} 
kavramına yeniden içerik kazandırılırken de hakikat rejimine göre hareket edilir. İşte Foucauldian literatürde hakikat, bu yönüyle kurulan, içeriği doldurulan bir inşadır. Dispositif olarak hukuk da hakikatin inşasıyla ilintili bir unsur olarak öne çıkmaktadır. Bu anlamda 1982 Anayasasının dispositifliği, norm koyarak hakikati tayin edici süreçteki işlevselliğiyle doğrudan ilgilidir.

Anayasanın bir diğer işlevi anayasal hak ve hürriyetler problemini, tehlikeli yaşamı sürekli hale getiren bir "tehdit algısı" üzerine temellendirmesinde görülebilir. Bahsedilen "tehdit algısı"nın tarihsel olarak da değişim yaşadığı safhalar söz konusudur. Bu noktada Mümtaz Soysal’a göre Türk anayasa tarihinin gelişim dinamiği 1920'lerden itibaren sarkaç gibi işlemiş, önce meclis üstünlüğüne dayalı iktidarların otoriter tutumlarına, oradan 1961 Anayasası'nın başka bir uçtaki özgürlükçü eğilimine ve nihayet 1971 ve 1980 müdahalelerinin birikimleriyle bu kez de yürütme üstünlüğüne dayalı bir otoriter anlayışa geçiş yapmıştır (1993: 17). Tanör açısından ise, 1982 Anayasası farklı bir özellik arz eder. 1982 Anayasası'nın temel hak ve hürriyetlerle ilgili bölümü, kişiyi siyasal iktidara karşı koruma güdüsüyle oluşturulan liberal anayasacılık fikrine karşı bir tepkiyle ortaya konulmuştur. Bu noktada 1982 Anayasası bir tersine çevirme işlemi uygulamış ve devleti kişiye karşı koruma şiârını benimsemiştir. Ancak Tanör, bahsedilen koruma refleksinin ziyadesiyle farklı ve Foucauldian argümanlarla uyumlu bir yönelimine daha vurgu yapmaktadır. Ona göre 1982 Anayasası devletle birlikte daha yoğunluklu olarak toplumu kişiye karşı koruma güdüsüyle hareket etmiştir (2019: 121).

Tanör'ün yaptığı vurgulama, toplumun savunulması gerektiği düşüncesiyle hareket eden ve tehlikelilik nosyonu ile potansiyel bir tehlikeli yaşam tasavvurunu geliştiren Foucauldian "modern toplum" şeması ile çakışır görünmektedir. 1982 Anayasası böylesi bir "toplumsal tehlikelilik" anlayışının hukuki formu olarak dışa vurmuştur. Selçuk Candansayar, yerleşikleşmiş tehlikelilik fikrinin, toplumun en küçüğünden en büyüğüne bir korku kültürü yarattığını, askeri iktidarın tüm topluma "ip hepinizin boğazında ve her an altınızdaki tabureyi devirebiliriz." mesajı verdiğini belirtmektedir (2010:4). Söz konusu durum, tüm medyanın denetim altına alındığı, üç-beş kişilik gruplar halinde yürümenin dahi yasaklandığı 12 Eylül konjonktüründe bütün ülke sathına "hepiniz benim gözümde vatan haini suçlularsınız. Önce hepinizi böyle kabul edip ona göre muameleye tabi tutacağım, ardından bana vatansever, iyi vatandaş olduğunu kanıtlayanlar temize çıkacaklar" mesajının verilmesidir (Candansayar, 2010: 4). Bahsedilen tehlikelilik nosyonu, Kenan Evren'in söylemlerinde de görülebilmektedir. Evren, darbenin gerçekleştirildiği 12 Eylül 1980'den 8 Şubat 1983'e kadar ele geçirilen 900 bin silah olduğunu bildirmiştir. Ne var ki bu sayı, o dönemde TSK'ya ait mevcut silah envanterinden de fazladır (Hürriyet, 9 Şubat 1983). Yer yer söylemsel yollarla rıza üreterek, yer yer hukuksal mekanizma ile normu dayatarak işleyen darbe süreci, Foucauldian perspektiften toplumu genel itibariyle travmatik ve kriminal bir özne olarak kurmuş bir iktidarın somut varlığının göstergesidir.

1982 Anayasanın 13. maddesinin orijinal hâlinde, temel hak ve hürriyetlerin sınırlandırılması ile ilgili olarak aşağıdaki ifadeler yer almaktadır:

"Temel hak ve hürriyetler, Devletin ülkesi ve milleti ile bölünmez bütünlüğünün, milli egemenliğin, Cumhuriyetin, milli güvenliğin, kamu düzeninin, genel asayişin, kamu yararının, genel ahlâkın ve genel sağlığın korunması amacı ile ve ayrıca Anayasanın ilgili maddelerinde öngörülen özel sebeplerle, Anayasanın sözüne ve ruhuna uygun olarak kanunla sınırlanabilir. 
Temel hak ve hürriyetlerle ilgili genel ve özel sınırlamalar demokratik toplum düzeninin gereklerine aykırı olamaz ve öngörüldükleri amaç dışında kullanılamaz." (Resmî Gazete, 1982).

Özgürlüklerin sınırına dair bu kargaşa, Tanör açısından "kaypak kavram bolluğu” olarak nitelendirilmektedir (2019: 122). Bizce bu kaotik çeşitlilik, iktidar ilişkilerinin mevzilendiği ve hakikati üreten dispositifsel aygıtın temel özelliğidir. 49 kişinin idam edildiği, işkenceden ötürü 171 kişinin öldürüldüğü, bir milyon 683 bin kişinin Alevi, Kürt(çü), komünist, dinci denilerek fişlendiği ve bu sürecin sakıncalı addedilen kişilerin komşularından, bakkallarından, terzilerinden bilgi alınarak yürütüldüğü bir dönemin temel hak ve hürriyetleri sınırlama saiklerinde bu sınır çizgilerini dönemin iktidar ilişkilerine kullanışı bir hakikat yaratma bağlamında çizdiği söylenebilir (Öndül, 2007). Foucauldian iktidarın, bilgi ve hakikat oyunu ile sarmal ağ teşkil eden formülasyonu, 12 Eylül'ün anayasal hak ve hürriyetlere bakışında ve yasanın söyleminde somutlaşmaktadır.

Tüm bunlarla birlikte 1982 Anayasasının devleti kutsal sayan ilk anayasa olduğu da belirtilmelidir. Anayasa kolektif hak ve hürriyetlere karşı özel bir duyarlılık göstermekte, toplantı ve gösteri yürüyüşü, dernek kurma hakkı, toplu çalışma ve eylem biçimlerine dair kısıtlamalar hususunda katı duyarlılık sergilemektedir. 1980 sonrası 23 bin 700 dernek faaliyetten men edilmiştir (T24, 12 Eylül 2016). Tüm kolektif sosyal haklar (sendika, grev, toplu sözleşme) için de sınırlamalar söz konusudur. Böylece Tanör açısından özgürlükler rejiminin sınırlandırılması durumu, olağan hal ve olağanüstü hal ayrımının değerini kaybettiği sürekli bir olağanüstü hali yerleşikleştirmiştir (2019: 128-131). Sürekli tehlikelilik potansiyelinin canlı tutulması iktidar rejimine uygun bir hukuksal dispositif olarak 1982 Anayasası ile mümkün kılınmıştır. Tanör'ün olağanüstü halin olağanlaşması diyerek bahsettiği süreç Foucauldian bakış ile tehlike üzerine kurulu toplumu önsel olarak varsayan ve güvenlikçi kodlarla işleyen risk toplumudur. 14 bin kişinin vatandaşlıktan çıkarıldığı, 650 bin kişinin gözaltına alındığı, 3 bin 854 öğretmen, 120 üniversite öğretim görevlisi ve 47 yargıcın işine son verildiği, sebebi belirsiz ve kuşkulu ölüm sayısının 419 olduğu, 210 bin davada 230 bin kişinin yargılandığı bir bilanço, bahsedilen risk toplumunun bir göstergesidir (Sercan, 2010: 25). Toplumun bazı kesimlerini terapi edilmesi gereken akıl hastası özneler olarak kuran iktidar rejimi, "tehlikeli" olarak işaretlediklerini dışlayıcı pratikler vasıtasıyla kriminal öznelere dönüştürmekte ve onların gerçekliğini üreterek bu özneleri bir toplumsal tehdit söyleminin nesneleri olarak kurmaktadır. Bu noktada hukukun, normu belirleyen ve normun dışında kalanı sabitleyerek disipline eden rolü ortaya çıkmaktadır.

Anayasanın 13. maddesinin 3 Ekim 2001 tarih ve 4709 sayılı "Türkiye Cumhuriyeti Anayasasının Bazı Maddelerinin Değiştirilmesi Hakkında Kanunla" ${ }^{15}$ değiştirilmiş şekli ise şu şekildedir:

"Temel hak ve hürriyetler, özlerine dokunulmaksızın yalnızca Anayasanın ilgili maddelerinde belirtilen sebeplere bağlı olarak ve ancak kanunla sınırlanabilir. Bu sınırlamalar, Anayasanın sözüne ve ruhuna, demokratik toplum düzeninin ve lâik Cumhuriyetin gereklerine ve ölçülülük ilkesine aykırı olamaz." (Resmî Gazete, 2001).

\footnotetext{
${ }^{15}$ Detaylı bilgi için bkz. 4709 Sayılı "Türkiye Cumhuriyeti Anayasasının Bazı Maddelerinin Değiştirilmesi Hakkında Kanun", T.C. Resmî Gazete, Tarih: 17.10.2001, Sayı: 24556.
} 
13'üncü maddenin eski hali ile yeni hali arasındaki benzerlikler; sınırlamanın kanunla yapılmasını uygun görmesi, sınırlamada Anayasanın sözüne ve ruhuna uygunluk şartı getirmesi, sınırlamayı Anayasanın ilgili maddelerinde öngörülen sebeplere dayandırması ve sınırlamanın "demokratik toplum düzeninin gereklerine" aykırı olmaması şartlarıdır. Değişiklikle gelen yenilikler ise, hakların özüne dokunma yasağı, ölçülülük ilkesi ve lâik Cumhuriyetin gereklerine uygunluk şartıdır (Gözler, 2001: 54-56).

Bu noktada değişiklik sonrası getirilen "hakların özü" ibaresinde Soysal'a göre bir hakka ya da özgürlüğe ilişkin özün nerede başladığı ve nerede bittiği ya da öz olmayanın nerede başladığı önceden belirlenemediğinden, yalnızca Anayasa Mahkemesi'nin bu konudaki kararına bağlı olarak bir çözüm yolu sunulmakla birlikte temelde kavrama dair bir sorun ve belirsizlik gözükmektedir. Aynı zamanda Soysal açısından bir anayasanın yürütmeyi güçlendirirken anayasal hak ve hürriyetleri sınırlaması zorunlu bir sonuç değildir. Hem yürütmeyi güçlendirmek hem de hak ve hürriyetleri güvence altında tutmak mümkündür. Ne yazık ki 1982 Anayasası yürütmeyi güçlendirirken anayasal hakları ve özgürlükleri keskin biçimde törpüleme yoluna gitmiştir (1993: 130132).

Hakların özü ile ilgili detaya dikkat çekmek gerekirse, bu vurgunun 1982 Anayasasının orijinal metninde yer almadığı görülmektedir. Bunun yerine "temel hak ve hürriyetlerle ilgili genel ve özel sınırlamalar demokratik toplum düzeninin gereklerine aykırı olamaz" (Resmî Gazete, 1982) ifadesinin tercih edildiği görülmektedir. Ne var ki sınırlııkların ölçütü olarak belirlenen bu kriterin olgusal düzeyde çok farklı bir görüntü çizdiği görülmektedir. 12 Eylül darbesinin ardından demokrasinin askıya alınmasıyla demokratik toplum düzeninin gerekleri de ortadan kaldırılmıştır. Binlerce sendikacı idamla yargılanmış, pek çok sendikacı yurt dışına kaçmış, bazılarının ise pasaportlarına el konulmuştur (Güler, 2019: 79-80). Siyasi partilerin kapatıldığı, parlamentonun feshedildiği ve tüm siyasi faaliyetlerin yasaklandığı bu dönem boyunca askeri iktidarın demokratik yol ve yöntemlerden çok güvenlik yatırımlarına yönelerek iktidar ilişkilerini sağlamlaştıran bir zemin oluşturulduğu görülmektedir. Örneğin, Emniyet Genel Müdürlüğü (EGM) bütçesi önceki yıllara oranla kat kat genişlemiştir. Ordunun sermaye sınıfıyla organik ilişkisini geliştiren Ordu Yardımlaşma Kurumu (OYAK) gibi, polis teşkilâtı da vakıflar ve dernekler eliyle sivil toplum alanında güçlendirilmiştir. Tıpkı 1965 yılında kurulan Toplum Zabıtası'nın 1961 Anayasası'nın özgürlükçülüğüne bir karşı tez olarak öne çıkması gibi, 12 Eylül sürecinde de benzer

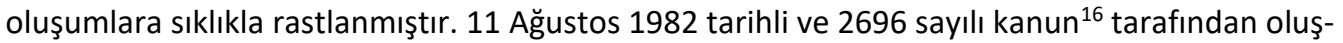
turulan Çevik Kuvvet örneği, Toplum Zabıtası ile benzerlik taşımış, toplum için tehdit arz eden "tehlikeli kimseleri" bastırma görevi görmüştür. Polis, sivil toplumu denetim altında tutarak iktidarı toplumsal düzeyde yeniden üretmekte, sermayenin dolaşımından öznelerin inşasına kadar çok geniş bir alanı kaplamaktadır. Başka bir ifadeyle polis, yalnızca suçla ilgili değildir, aynı zamanda vakıf yapısı sayesinde piyasaya entegre olmuş iktisadi bir aktördür. Polis teşkilatı, milli güvenlik söyleminin gölgesinde yükselmektedir (Demir ve Öztogay, 2017: 104-112). Böylece güvenlik toplumunun süreçteki uygulamalarına zıt olarak hakikati tayin eden ve normu dayatan yasanın aynı süreçteki dispositifsel niteliği görülebilmektedir.

Anayasal haklar düzeyinde bir diğer madde olan Anayasanın 17. maddesi şu şekildedir:

${ }^{16}$ Detaylı bilgi için bkz. "Polis Çevik Kuvvet Yönetmeliği”, T.C. Cumhurbaşkanlığı Mevzuat Bilgi Sistemi,

https://www.mevzuat.gov.tr/mevzuat?MevzuatNo=9225\&MevzuatTur=7\&MevzuatTertip=5 (Erişim: 3.08.2020). 
"Herkes, yaşama, maddî ve manevî varlığını koruma ve geliştirme hakkına sahiptir. Tıbbi zorunluluklar ve kanunda yazılı haller dışında, kişinin vücut bütünlüğüne dokunulamaz; rızası olmadan bilimsel ve tıbbi deneylere tâbi tutulamaz. Kimseye işkence ve eziyet yapılamaz; kimse insan haysiyetiyle bağdaşmayan bir cezaya veya muameleye tabi tâbi tutulamaz" (Resmî Gazete, 1982).

İşkence ve insan haysiyetiyle bağdaşmayan her türlü cezayı dışlayan anayasa maddesine rağmen, dönemin somut gerçekliği ve yürütülen disiplinci uygulamaların bedeni hedef alan politik anatomisi işkenceyi olağanlaştırmıştır. 12 Eylül mahkûmlarından Abdullah Delibalta o dönemde Diyarbakır Cezaevi'ndeki ${ }^{17}$ uygulamaları şöyle dile getirmektedir:

"O gün koğuş kapısı açıldı ve içeri 9-10 asker girdi. Başlarında Esat Oktay Yıldıran vardı. 'Sayım düzeni al' ve ardından da "Soyun" dediler. Aralarında 'Kara Bela' dediğimiz bir tim komutanı vardı. Bir de 'Laz' dediğimiz biri. Hepsinin elinde kalas vardı. Sonra Ali Sarıbal'ın, Hasan Çakır'ın ve Celal Türkmenoğlu'nun isimlerini okudular. Celal mahkemedeydi o gün, kurtuldu. Ali Sarıbal ve Hasan Çakır'ı ortaya alarak kalaslarla 15 dakika boyunca dövdüler. Biz esas duruşta duruyorduk. Hiçbir şey yapamıyorduk. İşleri bittiğinde Ali Sarıbal'ın boğazından hırıltılar geliyordu. Biraz sonra askerler gelip götürdüler. Ali o gün öldü" (Evrensel, 20 Eylül 2009).

Normalleştirici iktidarın ve kışla tipi pratiklerin darbe hapishanelerindeki mevcudiyeti bir diğer Diyarbakır Cezaevi mahkûmu Selim Dindar'in ifadelerinde de ortaya çıkmaktadır:

"Akşama kadar eğitim vardı. Sabah koğuşun içinde yüz kişi sıraya tutuluyorduk. Esas duruşta askeri marşlar söylüyorduk. 60'tan fazla marş ezberlemiştik. Eksik ya da yanlış söyledin diye, bu marş söylemeler dayaksız geçmiyordu. Her koğuşta mutlaka muhbirler ve gözetleme delikleri vardı. Birbirimizle konuşamıyorduk, oturamıyorduk. Hep ayaktaydık. 24 saat dayak vardı. Her an, gecenin 12'si, sabahın üçü, dördü, koğuşa bir bölük asker baskın yapabiliyordu. Haydar denilen kalaslarla, coplarla, su borularıyla dövülüyorduk. Öğleden sonraları, gardiyan bize 'Eğitime hazırlanın' komutu veriyordu. İste o zaman herkeste korkudan tuvalete gitme ihtiyacı doğuyordu" (Radikal, 23 Haziran 2003).

Bunlara ek olarak, Foucault'nun ifade ettiği modern cezalandırmanın ruhu baskılaması (1992: 19-20) durumu 12 Eylül örneğinde mahkûm Hasan Hayri Aslan'ın sözleriyle ortaya çıkmaktadır:

"Insanı canından bezdiren işkence cenderesi sıkıldıkça sıkılmıştı. Organ tahribatlarıyla sürüp giden fiziki, psikolojik ve manevi işkenceler durmadan çeşitlilik kazanıyor ve insanın tahammül gücünün bütün sınırlarını darmaduman ediyordu. Uykusuz, yorgun ve aç bırakılarak bütün bedensel fonksiyonları depreme uğratılmış insanlara daha nasıl eziyet edebiliriz diye kafa yoruyorlar. Belli ki dünyanın bilinen bütün zalimane işkence metotlarını biliyorlar ve uyguluyorlar" (Aslan, 2015: 80).

Cezaevlerinde işkencenin yanı sıra mahkûmlar üzerinden bir hakikat üretimi de söz konusudur. Hukuk-iktidar-disiplin üçgeninde mahkûm normlaşan yasanın dayattığı hakikatlere göre bir hakikat-dışılık uzamı olarak kabul edilmekte, disiplin eliyle normun sınırlarına sokulmakta ve

\footnotetext{
1712 Eylül sonrasında Askeri Cezaevi olarak kullanılan Diyarbakır Cezaevi, 1980 yılında Adalet Bakanlığı tarafından inşa edilmiş, tutuklular üzerinde ağır ve düzenli işkenceler uygulanmıştır. Bu cezaevinde uygulanan insanlık dışı muamelelere ve işkencelere "Diyarbakır Cezaevi Gerçeğini Araştırma ve Adalet Komisyonu" raporunda yer verilmiştir. Resmi rakamların belirttiğine göre 1981 ve 1984 yılları arasında cezaevinde 34 kişi hayatını kaybetmiş, onlarca kişi sakat bırakılmıştır (Fırat ve Topaloğlu, 2012: 76-77). Diyarbakır cezaevi “Dünyanın en kötü şöhretli 10 cezaevi” arasında yer alır (Hürriyet, 29 Nisan 2008).
} 
hizaya getirilmektedir. Bu yapılırken mahkûm hem üretilen hakikate zorlanmakta hem de hakikat üretiminin parçası olmaktadır. İtirafçıık, bu pratiklerden biri olarak karşımıza çıkmaktadır. 12 Eylül döneminde Metris Cezaevi mahkûmu Cafer Solgun'un ifadesiyle:

"Tekme-tokat ve cop darbeleri yağmur gibiydi. Üstüne de bu küfür ve hakaretler, istekler... Neden sonra durdular. Diğer dört arkadaşı alıp götürdüler. 'Sen bekleyeceksin,' dediler.

Toplam dört grupla birlikte saatlerce işkence gördüm orada. Ayakta duracak halim kalmamıştı. Güçlükle giyebilmiştim elbiselerimi. Her seferinde hakkımda biraz daha bilgilenmiş oluyorlardı" (Solgun, 2017: 133).

"Her seferinde hakkımda biraz daha bilgilenmiş oluyorlardı" ifadesinde görüldüğü üzere, mahkûm hem üretilmiş bir hakikatin nesnesi hem de hakikat üretiminin öznesi olarak işlev görmektedir. Tehlikelilik nosyonunun, kalbine yerleştiği modern toplumda hukuk, yasa ve yasa ihlali üzerinden değil; bireyleri dönüştürme stratejisi üzerinden işler (Foucault, 2015a: 220-223; 2015b: 186-198). Foucault'ya göre, yasaya tabii olmak hakikate tabii olmaktır. Yargıya kendimizi itiraf ettikçe hakikati üretir ve insan bilimlerinin hakikat oyununa dahil oldukça hakikat üretiminin nesnesi kılınırız. Bize dayatılan öznellik kiplerinin içerisinde tabiiyet konumları da bizi özne kılar (2011: 102-103). Yasa, arka planda vicdani uğultuları dindiren ve hakikat yaratarak kanaatleri yönlendiren norm olarak işlerken, disiplin ve gözetim aynı sürecin bedenler düzeyindeki iktidar teknolojisidir. Bu pratikler içerisinde mahkûm yalnızca işlediği suçu değil, kendisini itiraf etmeye zorlanır (Koloş, 2016: 325). Böylece hukuk da bireyi biçimlendirme noktasında iktidarbilgi korelasyonu düzeyinde diğer söylemlerle birleşir (Turkel, 1990: 170). Hukukun dispositifliğinin genel muhtevasını da bu işleyiş oluşturur.

Mahkûmların ifadeleri ve dönemin yukarıda verilen genel bilançosu insan onurunun ayaklar altına alan ceza uygulamalarını ortaya koymaktadır. Dönemin iktidarının kendi eliyle koyduğu anayasanın maddelerine aykırı işkenceler ve şiddet fiilleri gerçekleştirdiği görülmektedir ${ }^{18}$. Esasen Anayasanın ortaya koyduğu gerçeklik dönem iktidarının hakikat rejimidir. İktidar bu gerçekliği dayattığı normun dışında kalanları ıslah ederek biyoiktidar vasıtalarıyla işletmektedir.

Hakikat üretiminin yanı sıra bilgi-iktidar ekseninde temel anayasal hakların bir başka düzeyini oluşturan basım ve yayın hakkına dair Anayasanın 26. maddesindeki tutum ve somut gerçeklik aşağıdaki gibidir:

"Herkes, düşünce ve kanaatlerini söz, yazı, resim veya başka yollarla tek başına veya toplu olarak açıklama ve yayma hakkına sahiptir. Bu hürriyet resmî makamların müdahalesi olmaksızın haber veya fikir almak ya da vermek serbestliğini de kapsar. Bu fıkra hükmü, radyo, televizyon, sinema veya benzeri yollarla yapılan yayımların izin sistemine bağlanmasına engel değildir" (Resmî Gazete, 1982).

Söz konusu anayasa maddesi düşünce ve kanaatlerin basım ve yayınının özgürlüğüne dikkat çekmektedir. Öte yandan darbe iktidarının bazı kitapları yasaklaması ya da bazı eserlerin yayımlarına izin vermemesi gibi uygulamalarının Anayasanın bu maddesiyle ters düştüğü görülmektedir. Örneğin, askeri gözden düşürdüğü iddiası ile 1981 yılında Adalet Ağaoğlu'nun “Fikrimin İnce Gülü"; komünizm ve müstehcenlik iddiasıyla 1982 yılında Pınar Kür'ün 12 Mart'ı anlattığı ve bir devrim/devrimci aşkını ele alan "Yarın Yarın”ı ve işçi mücadelesini ve grevi vurguladığı

${ }^{18}$ Detaylı okumalar için bkz: Aslan, Hasan Hayri (2015). Diyarbakır 5 No'lu Cehenneminde Ölümden De Öte, i̇stanbul: Patika Kitap; Odabaşı, Yılmaz (2016). Eylül Defterleri, İstanbul: Siyah Beyaz Yayınları; Yılmaz, Ali (2013). Kara Arşiv/12 Eylül Cezaevleri, İstanbul: Metis Yayınları; Yıldız, Pamuk (2012). O Hep Aklımda/Bir Mamak Cezaevi Tanıklığı, Ankara: Ayizi Kitap Yayınevi. 
gerekçesiyle bir çocuk kitabı olan Işı Özgentürk'ün "Kuş Ne Yana Öter" adlı romanları ile Attila IIlhan'ın "Böyle Bir Sevmek" adlı şiir kitabı 1980'de toplatılmıştır. Aynı şekilde, Can Yücel'in "Rengâhenk" adlı eseri müstehcenlik iddiasıyla yasaklanmıştır. Mehmet Eroğlu'nun "Issızlığın Ortasında" adlı kitabı da 1980 Darbesi döneminde yayınevi tarafından sakıncalı bulunmuş, bazı kelimeleri ayrıştırılarak ancak beş yıl sonra basılabilmiştir. Yaşar Miraç'ın "Trabzonlu Delikanlı/Taliplerin Ağıdı/Gül Ekmek” isimlerine sahip üçleme kitabı ise, 1981 Mart’ında sıkıyönetim mahkemelerinde yargılanarak yedi yıl yasaklı kalmıştır (Kargıoğlu, 2017).

O halde Anayasanın "basım ve yayın" ile ilgili olan bu maddesinin aksine tüm bu uygulamalar, yasa ile toplumsal gerçekliğin tutarsızlığını göstermektedir. Tüm bu örnekler, hakikati belirleyenin iktidar ve bir iktidar aygıtı olarak hukuk olduğunu işaret etmektedir.

Temel hak ve hürriyetlerin sınırlandırılması ile ilgili olarak 1982 Anayasasının ele alınacak son maddesi olan 34. madde alttaki gibidir:

"Herkes, önceden izin almadan, silahsız ve saldırısız toplantı ve gösteri yürüyüşü düzenleme hakkına sahiptir.

Şehir düzeninin bozulmasını önlemek amacıyla yetkili idari merci, gösteri yürüyüşünün yapılacağı yer ve güzergâhı tespit edebilir.

Toplantı ve gösteri yürüyüşü düzenleme hakkının kullanılmasında uygulanacak şekil, şart ve usuller kanunda gösterilir (...)" (Resmî Gazete, 1982).

Adı geçen maddeye göre toplantı ve yürüyüşler yalnızca suç işlenmesinin önlenmesi hususunda engellenebilir. Yaygın şiddet eylemleri haricinde bir suçun salt işlenebilme potansiyeli, gösteri ve yürüyüş hakkının yasaklanmasının sebebi olamaz (Özgenç, 2018: 181). ${ }^{19}$ Fakat bu maddenin kapsamı iktidar tarafından esnetildiğinde demokratik bir prensip olarak her yürüyüşün veya gösterinin kısıtlanması mümkün görünmektedir. Özellikle kamu otoritesi lehine bırakılan kanunla düzenleme payı, suç işlenmesi ihtimali üzerinden işleyen güvenlik toplumu kodlarını işler kılmaktadır.

34. maddedeki temel problem, bahsedilen hak kapsamında yapılacak düzenlemenin şekil, şart ve usullerinin kanunda gösterilmesi durumudur. Kanuna yüklenen bu yetki, 1982 Anayasası'nın AïHS ile uyuşmazlığının başladığı noktadır. Böylece ilgili madde yürütmeye, geniş çaplı düzenlemeler yapabileceği bir alan açarak inisiyatif tanımıştır. Böylece idareye, uygun gördüğü hususlarda düzenleme yetkisi tanıyan anayasa maddesi, yürütme gücünü geniş bir takdir yetkisi ile donatmış, başka deyişle iktidar aygıtına dispositifsel bir mevcudiyet sağlamıştır. Öte yandan idareye tanınan bu yetkinin, 2911 sayılı Toplantı ve Gösteri Yürüyüşleri Kanunu20 ile "toplantılara güneş doğmadan başlanamayacağını" şart koyacak kadar hor kullanılmasına sebep olduğunun belirtilmesi gerekmektedir (Ergin, 2013).

\footnotetext{
${ }^{19}$ Anayasanın 34. maddesinin Avrupa İnsan Hakları Sözleşmesi (AiHS)'nin 11. Maddesinden neredeyse satırı satırına alındığını belirtmek gerekmektedir. AiHS Madde: 11: "1. Herkes barışçıl olarak toplanma ve dernek kurma hakkına sahiptir. Bu hak, çıkarlarını korumak amacıyla başkalarıyla birlikte sendikalar kurma ve sendikalara üye olma hakkını da içerir.

2. Bu hakların kullanılması, yasayla öngörülen ve demokratik bir toplum içinde ulusal güvenliğin, kamu güvenliğinin korunması, kamu düzeninin sağlanması ve suç işlenmesinin önlenmesi, sağığın veya ahlakın veya başkalarının hak ve özgürlüklerinin korunması için gerekli olanlar dışındaki sınırlamalara tabi tutulamaz. Bu madde, silahlı kuvvetler, kolluk kuvvetleri veya devlet idaresi mensuplarınca yukarda anılan hakların kullanılmasına meşru sınırlamalar getirilmesine engel değildir." (AiHS, 2010).

${ }^{20}$ Bkz. "2911 Sayılı Toplantı ve Gösteri Yürüyüşleri Kanunu”, Resmî Gazete, Tarih: 6.10.1983, Sayı: 18185.
} 
Maddeye ilişkin olarak yukarıda yer verilen detay 1961 Anayasası'nın özgürlükçü muhtevasında önemli yer teşkil eden toplantı ve gösteri yürüyüşleri hakkının düzenlendiği 34. maddenin 12 Eylül rejimi tarafından nasıl dokunulmadan bırakıldığını açıklamaktadır. Söz konusu madde, 1961 Anayasasının yurttaşa tanıdığı toplantı ve gösteri yürüyüşü hakkının düzenlenmesinde uygulanacak "şart ve usuller" in kanunda gösterileceğinden bahsederek esasen dolaylı biçimde iktidar etkisinden yana düzenleyici bir tutum takınmıştır. Başka bir deyişle, anayasanın 34. maddesinin düzenlenmesi kanun metnine bırakılmıştır. Böylece düzenleme adına bırakılan bu boşluk, 2911 sayılı "Toplantı ve Gösteri Yürüyüşleri Kanunu" ile tamamlanmış, bu kanunun 3. maddesinde (Resmî Gazete, 1983), "Herkes (...) kanunların suç saymadığı belirli amaçlarla gösteri ve yürüyüş düzenleme hakkına sahiptir" ibaresi ile suç sayılmayan amaçların içeriği doldurularak anayasa tahsis edilmiştir. Ardı sıra gelen 19. maddede ise doz artırılarak "idare (...) bütün toplantıları bir ayı geçmemek üzere yasaklayabilir” ifadesine yer verilir. Ertuğrul Kürkçü (2020)’ye göre bu düzenleme ile idareye yurttaşın amacından sual etme yetkesi tanınmıştır ${ }^{21}$. Böylece anayasanın meşrulaştırma, gizleme, gerçekliği kurma işlevlerinin iktidar ilişkileriyle bağıntısı görülebilmektedir. Hukukun bir dispositif olarak işlerliğinin ve iktidara hukuksal bir yaptırım ve belirleyicilik payı bırakan dispositif işlevinin somut bildirimleri de benzer şekilde ortaya çıkmaktadır. Öte yandan bu süreç, toplum üyelerinin gösteri ve yürüyüş yapma isteklerine yönelik potansiyel bir risklilik hesabı yapan, "suç sayılmayan amaçlar"ı tanımlayan hakikat rejiminin inşası anlamına da gelmektedir. Nitekim 12 Eylül iktidarı tüm bu yönleriyle bütüncül anlamda kimlik veren, öznelliğe boyun eğdiren ve denetleyen bir iktidar olarak sindirme ve kişiliksizleştirme operasyonları yürütmüştür. Mavioğlu'na göre, "Özgürlük isteme, bedeli ağır olur" diyerek boyun eğdiren bir iktidar söz konusudur (2006b: 159).

Özetle hukuk, 12 Eylül rejiminde iktidar ilişkilerinden koparılamaz. Yasa öncelikle bir hakikat yaratmaktadır. Yaratılan bu hakikat beraberinde potansiyel suçluluk ve güvenlik uygulamalarını getirmiştir. ${ }^{22}$ Riskliler ve toplumsal düzenin düşmanları yasa yoluyla icat edilmekte, kurumsallaşmıs tahakküm aygıtları yoluyla ise sindirilmekte ve kimliksizleştirilmektedir.

\section{Sonuç}

Bilgi ve söylemle girift bir ilişki barındıran modern yüzyılın iktidarları, öncelikle içlerinde doğdukları kapitalist ilişkileri korumak zorundadırlar. Çünkü bu tip iktidarlar bireyin potansiyel enerjisinden maksimum fayda sağlamaya çalışan ve bu noktada verimliliği toplumsal çıkarın merkezine koyan bir forma bürünmüşlerdir. İktidarın dayandığı yegâne kaynak nüfusun beşeri varlığı olduğuna göre, o halde toplumsal çıkarı oluşturacak ve üretecek olan yegâne özne de birey ve bireyler topluluğu olarak nüfus olacaktır. Bu durumda bireyi ve nüfusu hastaneler ve tımarhaneler aracılığıyla her tür hastalık ve anomaliden korumak gerekecektir. Liberal toplu-

\footnotetext{
${ }^{21}$ Ertuğrul Kürkçü politik aktivist, yazar ve 24. Dönem Halkların Demokratik Partisi (HDP) Mersin milletvekilidir. HDP onursal başkanı ve kurucularındandır. 1970'te Türkiye Devrimci Gençlik Dernekleri Federasyonu Genel Başkanlığı yapmıştır. Demokrat Dergisi, Özgür Gündem, Evrensel gibi gazetelerde köşe yazarlığı da yapmış olan Kürkçü, Binaet.org'un da kurucuları arasında yer alır. Detaylı bilgi için bkz. Türkiye Büyük Millet Meclisi,

https://www.tbmm.gov.tr/develop/owa/milletvekillerimiz sd.bilqi?p donem=24\&p sicil=6955 (Erișim: 23.07.2020).

2212 Eylül'ün genel bilançosu şu şekilde verilebilir: 650 bin gözaltı, 1 milyon 683 bin fişleme, 210 bin dava, Sıkıyönetim mahkemelerinde 230 bin yargılama, 14 bin vatandaşlıktan çıkarma, 229 toplam ölüm, 144 kuşkulu ölüm, 171 işkence ile ölüm, 43 intihar, hakkında işlem yapılan 7 bin 245 memur ve 3 bin 854 öğretmen, 47 hâkim-savcı, 120 öğretim üyesi, görevine son verilen 4891 çalışan, gazetecilere yönelik toplam 3315 yıl hapis, 1989'da 16 günlük gazeteye açılan toplam 394 dava, yakılarak yok edilen 39 ton gazete, dergi, kitap, basın özgürlüğünü kısıtlayan 151 yasa, tüm sürecin yalnızca öne çıkan rakamlarıdır (T24, 12 Eylül 2016).
} 
mun savaşı verimsizliğe karşı savaştır. Kapitalist üretim süreçlerinin hiçbir aşamasında yer alamayan bir deli veya yine aynı toplumsal çıkar için tehdit arz eden bir yoksul, kendisini bu savaşın tam ortasında bulur. Onlar, nüfus içindeki verimsiz anormallerdir, bir dişlinin işlemeyen çarkı gibidirler. Böylece toplum var oldukça toplum dışılar da var olmaktadır. Bu "alt sınıflar", çeşitli sıfatlarla kendilerinin seçmedikleri toplumsal kompartımanlara yerleştirilerek tasnif edilirler.

O halde bu sindirme mekanizmaları hukuk, cezaevleri ve tımarhaneler gibi aygıtlarla birlikte sistematik olarak işleyecektir. Temel faktör "ikna etme" olsa da ikna olmayanları bir rehabilitasyon merkezine, bir tımarhaneye, düşkünler evine ya da hapishaneye kapatmak gerekecektir. Toplumun hiç durmadan yeniden üretimi söz konusu olduğunda, bu üretim sürecine cevap vermeyen birey hiç düşünülmeksizin un ufak edilebilir. Piyasa ilişkileri, kâr maksimizasyonu ve toplumsal üretim süreci, yolunun üzerindeki her pürüzü yok ederek yoluna devam eder, artık farklılıklara yer yoktur.

Öte yandan tekil bir tarihsel dönemin yapısökümü söz konusu olduğunda bilgi dizgeleri ile iktidar rejimleri, söylemsel pratikler ile hakikat oyunları arasındaki bütüncül mekanizma yine liberal/neoliberal yönetimsellik şeması içerisinde işlemektedir. 1980 darbe süreci de dünya iktisadi sistemine eklemlenen Türkiye'de, bahsedilen bütüncül mekanizmanın somut örneğini teşkil etmektedir. Disiplinci politik anatominin hapishaneler düzeyinde, düzenleyici biyopolitiğin ise bütçesi artırılan kolluk güçleri gibi güvenlik örüntülerini yansıtan düzeylerde hayata geçirilmesinin yanında hukuk, hakikat rejiminin inşası noktasında dispositif olarak anlam kazanmıştır. Bununla birlikte devlet politikası haline getirilen Türk-islam sentezinden komünizm düşmanlığına ve irtica tehdidine kadar yeni bir devlet aklının, risk toplumunu her öğesiyle patolojik özne olarak işaretlediği ve yeni bir devlet rasyonalitesi inşa ettiği görülmektedir.

Bu açıdan 12 Eylül süreci tüm yönleriyle analiz edilirse anlam kazanacaktır. Darbenin hemen akabinde küresel neoliberalizme eklemlenecek olan Türkiye'de darbe iktidarı büyük bir gözaltı laboratuvarı gibi işlemiştir. Bu laboratuvarın temel dayanağını oluşturan fikri yapı ise hukuksal aygıttır. Hukuksal altyapı, darbenin sert yüzünü ve politikalarını meşru kılmış, muhayyel bir "potansiyel tehdit" algısıyla, toplumun bilinç ilişkilerini dilediği gibi yönlendirerek kendince bir özne tasarlamıştır. Nitekim anayasal hak ve hürriyetlerin ihlali ve daha genel olarak hukuk-iktidar ilişkisinin bağıntısı açısından 1982 Anayasası, bahsedilen toplumsal tasarımın en kesin şekilde billurlaştığı bir aygıt, normun sınırlarını çizerek söylem ve hakikat ile iç içe geçmiş bir dispositif tir. 


\section{Kaynakça}

Agamben, Giorgio (2012), Dizpozitif Nedir? /Dost, (Çev. Ekin Dedeoğlu), İstanbul: MonoKL Yayınları.

Ahmad, Feroz (1995), Modern Türkiye'nin Oluşumu, (Çev. Yavuz Alogan), 1. Baskı, İstanbul: Sarmal Yayınevi.

Akgündüz, Gülay Ö (2013), “Foucault'da İktidar ve Beden İlişkisi”, Akademik Bakış Dergisi, S. 38: 1-16.

Althusser, Louis (1978), Ideoloji ve Devletin Ideolojik Aygıtları, (Çev. Yusuf Alp, Mahmut Özışı), 1. Baskı, İstanbul: Iletişim Yayınları

Artières, Philippe ; Quéro, Laurent ; Zancarini-Fournel, Michel (2003), Le groupe d'information sur les prisons, Archives d'une lutte, 1970-1972. Paris: IMEC Yayınları.

Aslan, Hasan Hayri (2015), Diyarbakır 5 No'lu Cehenneminde Ölümden De Öte, 1. Baskı, İstanbul: Patika Kitap.

Aydın, Suavi; Taşkın, Yüksel (2014), 1960'tan Günümüze Türkiye Tarihi, İstanbul: İletişim Yayınları

Becermen, Metin (2009), Theodor W. Adorno ve Michel Foucault'da Hakikat ve Iktidar Ilişkisi, Yayımlanmamış Doktora Tezi (Hacettepe Üniversitesi Sosyal Bilimler Enstitüsü).

Belge, Murat (1992), 12 Yıl Sonra 12 Eylül, İstanbul: Birikim Yayınları.

Bentham, Jeremy (2008), Panoptikon: Gözün Iktidar, İstanbul: Su Yayınevi.

Birol, Sanem (2012), "1961 Anayasasında İfade Özgürlüğü”, İstanbul Üniversitesi Iletişim Fakültesi Dergisi, S. 43: 39-54.

Candansayar, Selçuk (2010), "12 Eylül 1980: Korku Çağında Eriyen Akıllar”, Türkiye Psikiyatri Derneği Bülteni, C. 13, S. 2: 3-5.

Cevizci, Ahmet (1999), Felsefe Sözlüğü, 3. Baskı, İstanbul: Paradigma Yayınları.

Cizre, Ümit (2004), "Egemen İdeoloji ve Türk Silahlı Kuvvetleri: Kavramsal ve Illişkisel Analiz", (Ed. Ahmet İnsel ve Ali Bayramoğlu), Bir Zümre Bir Parti Türkiye'de Ordu, İstanbul: Birikim: 135.

Çalkıvik, Aslı (2011), “'Ölümüne Yaşatmak': Güvenlik Sorunu Olarak 'Yaşam””, Toplum ve Bilim Dergisi, S. 122: 1937.

Çelebi, Vedat (2013), "Michel Foucault'da Bilgi, İktidar ve Özne ilişkisi”, Sosyal ve Beşerî Bilimler Dergisi, C. 5, S. 1: 512-523.

Demir, Gökhan; Öztogay, Dünya A. (2017), "İstisnai Devlet Biçimi ve Polis: 12 Eylül Döneminde İç Güvenlik Aygıtının Yeniden Yapılandırılması”, Amme Idare Dergisi, C. 50, S.1: 85-116.

Duran, Lütfi (1984), "Türkiye'de Anayasa Yargısının İşlevi ve Konumu”, Amme Idare Dergisi, C. 17, S. 3: 3-27.

Duverger, Maurice (1995), Siyaset Sosyolojisi, İstanbul: Varlık Yayınları.

Eroğlu, Hülya Ö. (2016), “Foucault’nun İktidarları”, Amme Idare Dergisi, C. 49, S. 2: 39-54.

Fırat, Derya; Topaloğlu, Hande (2012), “Diyarbakır Askerî Cezaevi (1980-84)”, Toplum ve Bilim Dergisi, S. 123: 7692.

Foucault, Michel (1988), Politics, Philosophy, Culture: Interviews and Other Writings, (1977-1984), (Trans. Alan Sheridan and Others), Londra: Routledge.

Foucault, Michel (1992), Hapishanenin Doğuşu, Ankara: İmge Kitabevi (Çev. Mehmet Ali Kılıçbay).

Foucault, Michel (1999), Bilginin Arkeolojisi, (Çev. Veli Urhan), 3. Baskı, İstanbul: Birey Yayıncılık.

Foucault, Michel (2000), Power, (Çev. Robert Hurley vd.), New York: The New Press.

Foucault, Michel (2001a), Dits et écrits I. 1954-1975, Paris: Editions Quarto Gallimard.

Foucault, Michel (2001b), Kelimeler ve Şeyler, (Çev. Mehmet Ali Kılıçbay), 2. Baskı, Ankara: İmge Kitabevi.

Foucault, Michel (2003), Cinselliğin Tarihi, (Çev. Hülya Uğur Tanrı̈ver), 1. Baskı, İstanbul: Ayrıntı Yayınları

Foucault, Michel (2011), Entelektüelin Siyasi İşlevi, (Çev. Işık Ergüden, Osman Akınbay ve Ferda Keskin), İstanbul: Ayrıntı Yayınları.

Foucault, Michel (2013), Güvenlik, Toprak, Nüfus, (Çev. Ferhat Taylan), 1. Baskı, İstanbul: İstanbul Bilgi Üniversitesi Yayınları.

Foucault, Michel (2015a), Büyük Kapatılma, (Çev. Işık Ergüden, Ferda Keskin), 4. Baskı, İstanbul: Ayrıntı Yayınları.

Foucault, Michel (2015b), iktidarın Gözü, (Çev. Işık Ergüden), 4. Baskı, İstanbul: Ayrıntı Yayınları.

Foucault, Michel (2015c), Toplumu Savunmak Gerekir, (Çev. Şehsuvar Aktaş), 7. Baskı, İstanbul: Yapı Kredi Yayınları. Foucault, Michel (2016), Özne ve Iktidar, İstanbul: Ayrıntı Yayınları (Çev. Işık Ergüden, Osman Akınhay).

Golder, Ben; Fitzpatrick, Peter (2009), Foucault's Law, Oxon: Routledge. 


\section{Eskişehir Osmangazi Üniversitesi İktisadi ve İdari Bilimler Fakültesi Dergisi}

Gödelek, Kamuran (2011), "Michel Foucault'nun Ahlak Anlayışı", Beytulhikme An International Journal of Philosophy, C. 1, S. 2: 39-61.

Gökhan, Demir; Öztogay, Dünya A. (2017), "İstisnai Devlet Biçimi ve Polis: 12 Eylül Döneminde İç Güvenlik Aygıtının Yeniden Yapılandırılması”, Amme Idare Dergisi, C. 50, S. 1: 85-116.

Gözler, Kemal (2001), "Anayasa Değişikliğinin Temel Hak ve Hürriyetlerin Sınırlandırılması Bakımından Getirdikleri ve Götürdükleri (Anayasanın 13'üncü Maddesinin Yeni Şekli Hakkında Bir İnceleme)”, Ankara Barosu Dergisi, S. 4: 5367.

Güler, Ceyhun (2019), "Darbe, Dayanışma ve Direniş: 1980 Dönemi Avrupa Sendikal Hareketi ve DisK İlişkileri”, Çalışma ve Toplum Ekonomi ve Hukuk Dergisi, S. 60: 79-104.

Güneş, Cevriye D. (2013), “Michel Foucault'da Söylem ve Iktidar”, Kaygı Uludağ Üniversitesi Fen-Edebiyat Fakültesi Felsefe Dergisi, S. 21: 56-69.

Gürsoy, Yaprak (2014), "Türkiye'de Sivil Asker illişkilerinin Dönüşümünün Sebepleri”, Uluslararası iliş̧iler, C. 11, S. 43: 157-180.

Hunt, Alan (1992), “Foucault's Expulsion of Law: Toward a Retrieval”, Law\&Social Inquiry, Vol. 17, No. 1: 1-38.

Işık, Sever (2012), "Foucault'da İktidar, Özgürlük ve Direniş", Ekev Akademi Dergisi, S. 51: 103-114.

Kargıŏlu, İrem (2017), “Darbe Döneminde Yasaklanan Kitaplar”, Pan Dergi, S. 4.

Karpat, Kemal H. (2010), Türk Demokrasi Tarihi/Sosyal, Kültürel, Ekonomik Temeller, 1. Baskı, Istanbul: Timaş Yayınları.

Keskin, Ferda (2015), “Sunuş: Büyük Kapatılma”, (Yaz. Michel Foucault), Seçme Yazılar-3: Büyük Kapatılma, (Çev. Işık Ergüden, Ferda Keskin), İstanbul: Ayrıntı Yayınları.

Kılıç, Muharrem (2014), “Bilgi-iktidar illişkisi Bağlamında Yasa Düşüncesi: İktidarın Yasal(I)aşması”, İstanbul Üniversitesi Hukuk Fakültesi Mecmuası, C. 72, S. 1: 173-188.

Koloş, Umut (2016), Foucault, iktidar ve Hukuk/Modern Hukukun Soy bilimi, İstanbul: İstanbul Bilgi Üniversitesi Yayınları.

Leonard, Jerry D. (1990), “Foucault: Geneaology, Law, Praxis”, Legal Studies Forum, Vol. 14, No. 1: 3-25.

Mahçupyan, Etyen (2002), “Bir Mikro İdeoloji Olarak Militarizm”, Birikim Dergisi, S. 160-161: 49-56.

Mavioğlu, Ertuğrul (2006a), Apoletli Adalet/Bir 12 Eylül Hesaplaşması-2, İstanbul: İthaki Yayınları.

Mavioğlu, Ertuğrul (2006b), Asılmayıp Beslenenler/Bir 12 Eylül Hesaplaşması -1, İstanbul: İthaki Yayınları.

Milliyet Gazetesi, “Ordunun Yönetime Gelmesi Dışta Olumlu Karşılandı” 13 Eylül 1980: 6.

Mumcu, Ahmet (1986), "1924 Anayasası”, Atatürk Araştırma Merkezi Dergisi, C.2, S. 5: 383-400.

Neocleous, Mark (1996), Administering Civil Society: Towards a Theory of State Power, Houndmills, Basingstoke, Hampshire and Lonra: Macmillan Press; New York: St. Martin's Press.

Örs, Birsen (2010), “ideoloji: Karmaşık Dünyayı Anlaşılır Kılmak”, (Ed. Birsen Örs), 19. Yüzyıldan 20. Yüzyıla Modern Siyasal İdeolojiler, 7. Baskı, İstanbul: İstanbul Bilgi Üniversitesi Yayınları: 32-38.

Özgenç, İzzet (2018), "Toplantı ve Gösteri Yürüyüşü Hürriyeti ile Seyahat Hürriyeti Bağlamında Özgürlük ve Güvenlik İlişkisi”, Anayasa Yargısı, C. 35, S. 1: 175-194.

Sarup, Madan (2004), Post-yapısalcılık ve Post-modernizm, (Çev. Abdülbaki Güçlü), 2. Baskı, Ankara: Bilim ve Sanat Yayınları.

Sercan, Mustafa (2010), "Psikiyatrinin 12 Eylül'ü”, Türkiye Psikiyatri Derneği Bülteni, C. 13, S. 2: 25-29.

Solgun, Cafer (2017), “Demeyin Anama, İçerdeyim”, İstanbul: İletişim Yayınları.

Soysal, Mümtaz (1993), 100 Soruda Anayasanın Anlamı, İstanbul: Gerçek Yayınevi.

Tanör, Bülent (2019), iki Anayasa: 1961-1982, 5. Baskı, İstanbul: On İki Levha Yayıncılık.

Tekelioğlu, Orhan (1999), Michel Foucault ve Sosyolojisi, İstanbul: Bağlam Yayıncılık.

Therborn, Göran (2008), iktidarın Ideolojisi Ideolojinin iktidarı, Ankara: Dipnot Yayınları.

Timur, Taner (2005), Felsefi İlenimler, 1. Baskı, Ankara: İmge Kitabevi.

Topuzkanamış, Engin (2019), “Foucault’nun Düşüncesinde Hukuk ve İktidar”, Dokuz Eylül Üniversitesi Hukuk Fakültesi Dergisi, C. 21, Özel S. : 1833-1850.

Turkel, Gerald (1990), “Michel Foucault: Law, Power and Knowledge”, Journal of Law and Society, Vol. 17, No. 2: 170-193. 
Urhan, Veli (2007), “M. Foucault ve Bilgi/iktidar İlişkisinin Soykütüğü”, Kaygı: Uludağ Üniversitesi Fen Edebiyat Fakültesi Felsefe Dergisi, S. 9: 99-118.

Urhan, Veli (2010), Foucault, 1. Baskı, İstanbul: Say Yayınları.

Üstel, Füsun (2002), "Türkiye Cumhuriyeti'nde Resmî Yurttaş Profilinin Evrimi”, (Ed. Tanıl Bora ve Murat Gültekingil), Milliyetçilik, İstanbul: Illetişim Yayınları: 275-284.

Üstel, Füsun (2004), “Makbul Vatandaş”ın Peşinde/II. Meşrutiyet'ten Bugüne Vatandaşlık Eğitimi, İstanbul: Illetişim Yayınları.

Valencia-Villa, Hernando (1981), “Foucault and the Law: An Antijuridical Jurisprudence?”, Philippine Law Journal, Vol. 56, No. 3: 355-366.

Zürcher, Eric J. (1995), Modernleşen Türkiye'nin Tarihi, (Çev. Yasemin Saner Gönen), 1. Baskı, İstanbul: illetişim Yayınları.

“Evren: Taviz Devri Bitti”, Hürriyet, 09.02.1983, S. 14.

“Avrupa İnsan Hakları Sözleşmesi (2010)”, Danıştay, https://www.danistay.gov.tr/upload/avrupainsanhaklarisozlesmesi.pdf (Erişim: 28.07.2020).

“Bir 12 Eylül Cehennemi: Diyarbakır Zındanı”, Evrensel, 20 Eylül 2009, https://www.evrensel.net/haber/197849/bir-12-eylul-cehennemi-diyarbakir-zindani, (Erişim: 02.07.2020).

“Diyarbakır Cezaevi Dünyada En Kötü 10 Arasında", Hürriyet, 29.04.2008, https://www.hurriyet.com.tr/gundem/diyarbakir-cezaevi-dunyada-en-kotu-10-arasinda-8811243\#: :text=The\%20Times\%20gazetesi\%2C\%20\%E2\%80\%9CD\%C3\%BCnyan\%C4\%B1n\%20en,daki\%20Canandiru\%20Cezaevi'ni\%20s\%C4\%B1ralad\%C4\%B1, (Erişim: 28.06.2020).

Ergin, Sedat, "Gösteri Özgürlüğünün Sınırları (1): AiHM Kararları 12 Eylül Yasasını Geçersiz Kıldı", Hürriyet, 02.07.2013, https://www.hurriyet.com.tr/gosteri-ozgurlugunun-sinirlari-1-aihm-kararlari-12-eylul-yasasini-gecersizkildi-23631791 (Erişim: 26.07.2020).

"Ertuğrul Kürkçü", Türkiye Büyük Millet Meclisi, https://www.tbmm.gov.tr/develop/owa/milletvekillerimiz sd.bilgi?p donem=24\&p sicil=6955 (Erişim: 23. 07.2020).

“Genelkurmay ve Milli Güvenlik Konseyi Başkanı Orgeneral Kenan Evren'in Türk Milletine Açıklaması”, T.C. Resmî Gazete, 12.09.1980. https://www.resmigazete.gov.tr/arsiv/17103 1.pdf (Erişim: 29.07.2020).

Gözler, Kemal. "Referandum mu, Plebisit mi?”, anayasa.gen.tr, 05.03.2017, http://www.anayasa.gen.tr/plebisit.pdf (Erişim: 13.07.2020).

Keskin, Ferda. "Toplum ve Siyaset (14): Foucault: Özne ve Iktidar", Youtube, 04.05.2017, https://www.youtube.com/watch?v=AbmKP08bySo, (Erişim: 17.04.2019).

Koloş, Umut. "Foucault ve Hukuk Tartışmalarına Katkı: Dispositif Olarak Hukuk - I", yenihukuk.blogspot.com, 09.09.2013, http://yenihukuk.blogspot.com/2013/09/foucault-ve-hukuk-tartsmalarna-katk.html (Erişim: 19.04.2019).

Kürkçü, Ertuğrul, "Yürümek...", Yeni Yaşam, 11.06.2020, http://yeniyasamgazetesi1.com/yurumek/, (Erişim: 1.07.2020).

Öndül, Hüsnü. "Geçmişle Yüzleşme: 12 Eylül Travmasını Aşmak", Insan Hakları Derneği, 14.09.2017, https://www.ihd.org.tr/gecmisle-yuzlesme-12-eylul-travmasini-asmak/ (Erişim: 14.06.2020).

“T.C. Anayasası (1961)", T.C. Resmî Gazete, 20.07.1961, https://www.resmigazete.gov.tr/arsiv/10859.pdf (Erişim: 8.07.2020).

“T.C. Anayasası (1982)”, T.C. Resmî Gazete, 20.10.1982, https://www.resmigazete.gov.tr/arsiv/17844.pdf (Erişim: 12.07.2020).

"Toplantı ve Gösteri Yürüyüşleri Kanunu", T.C. Resmî Gazete, 06.10.1983, https://www.resmigazete.gov.tr/arsiv/18185.pdf, (Erişim: 4.07.2020).

"Üç Yılını Cehennemde Geçirdi", Radikal, 23.06.2003, http://www.radikal.com.tr/turkiye/uc-yilini-cehennemdegecirdi-673856/, (Erişim: 20.06.2020).

“12 Eylül: Türkiye Tarihinin En Karanlık Askeri Darbesinin Üzerinden 36 Yıl Geçti”, T24, 12.09.2016, https://t24.com.tr/haber/12-eylul-turkiye-tarihinin-en-karanlik-askeri-darbesinin-uzerinden-36-yil-gecti,359472, (Erişim: 3.07.2020). 


\section{Eskişehir Osmangazi Üniversitesi İktisadi ve İdari Bilimler Fakültesi Dergisi}

\section{Extended Summary}

A Foucauldian Look at the 1982 Constitution in Terms of Fundamental Constitutional Rights and Freedoms

According to the philosopher Michel Foucault, omnipresent power results from diverse and complex processes of interaction between individuals. So, there is not just one power, the political power of the state, but multiple powers within society. “(....) Society is an archipelago of different Powers" says Foucault (Brazil 1976 Conference "Les mailles du pouvoir 1 ère partie" in Dits et Écrits, 1981). Corresponding then to a social relationship and involving unequal and mobile relationships between individuals or between groups as stated by Foucault, power is linked to knowledge. It is first of all the institution of power which creates knowledge by producing concepts which legitimize its existence and serve for its proper functioning. The question of power poses in parallel the problem of the subject, subjectivity, the self, which is one of the most complex problems in Foucauldian thought. The philosopher also specifies that it is not power but the subject that constitutes the theme of his research. He emphasizes wanting to produce a history of the different modes of subjectivation of human beings in Western culture, to this end, he deals with modes of objectification that transform human beings into subjects. On the other hand, Foucault draws attention to the subject's direct relationship with truth that he believes has no essence. The truth certainly exists, but the philosopher rejects the idea of its relative character. It is rather the way in which truth is produced or how it can be constituted in a power relationship that interests Foucault ("Le sujet et le pouvoir" in Dits et Écrits, 1982).

The question of power is then situated in relation to the question of the production of knowledge and the will to truth. The subject internalizes behavioural practices consistent with the truths produced by the knowledge itself produced by the institution of power. This is the constitution of the subject by power. Foucault thus very firmly separates the subject of law and the moral subject which imply different modes of subjectivation. The first, the mode of subjectivation of the institution of power which operates through the constitution of knowledge and the second, the subjectivation by acquiring self-knowledge through ethics.

The institution of power works thanks to the non-discursive practices (institutions, laws, administrative procedures, etc.) that Foucault calls "dispositifs". Over the course of his work, through the notion of "dispositif of power", Foucault first decoded power relations, and then corrected his analysis by including them in the issue of "biopower" and "biopolitics". The notion of dispositif cannot be separated from that of power. It is even at every turn a dispositif of power-knowledge. The dispositifs are the set of practices for recognizing power relations and using force when necessary. The legal provisions therefore constitute dispositifs.

Three different approaches can be found in Foucault's literature on the place of the legal apparatus in power relations: according to the first approach, that of "the expulsion thesis", Foucault would have "expelled" the law of the historical and political analysis of modernity where practices such as surveillance, control and discipline exist. On the contrary according to the second approach, the philosopher does not exclude the law in modernity, on the contrary modern power is based on law. At the same time, just as power produces knowledge, law also produces knowledge, hence law does not completely disappear in modernity. The last approach is that of law as a dispositif of power. Here, the set of norms constructing the truth on which the disciplinary power is based, constitute the law.

The military regime of September 12, 1980 in Turkey can be analysed in the light of the Foucauldian philosophy briefly presented thus far. The military regime established after the September 12 coup has created a regime of truth both in discourse and in law. Thus, the 1982 constitution introduced after the coup functioned as a source of truth legitimizing the institution of power. The legal mechanism which assumes objective legality substantially mobilizes power relations in a historical context. In this context, the liberal and democratic character of the previous constitution of 1961 loses its original weight in the constitution of 1982 which imposed on society the perception of dangerous life. In practice, the articles of the constitution relating to fundamental rights and freedoms have been violated due to additions which were made giving rise to the attribution of new meanings to them. For example, although the practice of torture goes against the constitution, it was practiced on numerous occasions. Prisons have become places where the institution of military power subjectivizes prisoners. Likewise, while the freedom of the press and of publication and the right of assembly and demonstration are guaranteed in the constitution, during the military regime many books were banned, and special power was granted to public authorities for arbitrary restrictions. Therefore, the constitution of 1982 seems to embody the Foucauldian disciplinary mechanisms, and security apparatuses. However, knowing that wherever power is found there is resistance, the existence of people who stand up to the practices of subjectivation of power-knowledge in the prisons of the military regime of 1980 such as those of Diyarbakır and Mamak, should be noted.

These prisons can be presented as "panopticon" models where, according to Foucault, the power exercised over bodies and minds manifests itself. Finally, Foucault undertook an analysis of the forms of liberal governmentality and thus referred to the practices relating to security and surveillance inherent in liberalism (The Birth of Biopolitics). Indeed, political reforms were carried out after the 1980 coup d'État in Turkey with a view to financial liberalization, trade liberalization, price reform and currency convertibility. This allowed the country to integrate into the global economy and facilitated the formation of a new raison d'état making possible this economic transformation. 